\title{
Early Shows and Sales of Islamic Antiques in Paris
}

Early displays of Islamic arts and crafts in nineteenth-century Europe are commonly associated with a set of shows that were held between 1885 and 1910 in London (Exhibition of Arab and Persian Art, 1885), Paris (Les Arts musulmans, 1893 and 1903), Stockholm (F. R. Martins Sammlungen aus dem Orient within the General Art and Industry exhibition, 1897), Algiers (Exposition d'art musulman, 1905) and Munich (Meisterwerke Muhammedanischer Kunst, 1910). ${ }^{1}$ These did not represent however the first or sole opportunities for direct exposure to artworks from the Eastern Mediterranean and North Africa that were offered to European audiences during the age of empire, industry and spectacle. Every single Universal Exposition since 1851 presented objects from the region, ${ }^{2}$ whether they were the product of current craftsmanship or "curiosities" from the past - the common term then used for non-Western artworks. ${ }^{3}$ From the very beginning, shows devoted to applied arts, routinely described as industrial, ornamental or decorative in the sources, also hosted Islamic artefacts among their exhibits; alternative viewing was thus provided to those who had not travelled East. More

1 Vernoit, Discovering Islamic Art, 18; Komaroff, "Exhibiting the Middle East," 1-8; Labrusse, Purs décors, 64-74; Chris Dercon et al., The Future of Tradition.

2 Chromolithographs by Joseph Nash depict the Tunisian, Egyptian, Turkish, and Persian exhibits at the Great Exhibition of 1851 in London, see Dickinson's Comprehensive Pictures of the Great Exhibition of 1851, from the originals, painted for H. R. H. Prince Albert, by Messrs. Nash, Haghe and Roberts (London: Dickinson brothers, 1854). The Tunisian case is explored in Isabelle Weiland, "La Tunisie aux expositions universelles de 1851 à 1900" (PhD diss., École des Hautes études en sciences sociales, 2013).

3 Michael Hall's introduction to "Bric-à-brac: A Rothschild's memoir of collecting," Apollo, no. 545 (July-August 2007): 50-77 (53). importantly, the presence of such collectibles in Europe did not depend on European agency alone; Middle Eastern actors also took part in the European exposure of such objects. From the outset, the Western appraisal of Islamic antiques was embedded into transnational dynamics working in both directions.

Three interconnected public events, closely linked to the rise of these collectibles on the art market, helped to further the extent of European encounters with historic artworks from the Middle East and the interactions that sustained them. All took place in Paris during the late Second Empire. The earliest is the loan show organised by the Union centrale des beaux-arts appliqués à l'industrie in 1865. For the first time French collectors and amateurs were publicly showing their specimens in applied arts, either Western artefacts, or pieces from elsewhere, the Islamic world included. This circumstance provides a unique opportunity to explore the range and type of Islamic collectibles then held in French private hands. An Egyptian display at the Exposition universelle of 1867 subsequently brought to international attention a substantial amount of Islamic salvage. Two auction sales connected to both exhibitions followed in 1868 and 1869 .

Some information can be retrieved on each event and their contents by mining an array of heterogeneous data. Visual records exist for a fraction of the artworks exhibited in 1865. Those depicted by photography, together with the ones only known through written descriptions, pop up in loan records, press clippings, exhibition catalogues or auction minutes. Some artworks photographed at the 1865 show can be traced down to museums today, where further data on their origin, style and provenance are retrievable. Piece by piece, insights can be gained on

(C) MERCEDES VOLAIT, 2021 | DOI:10.1163/9789004449886_003 
the objects concerned, the players involved, and the economics at stake. In other words, a collective biography of Middle Eastern artworks in Parisian hands during the 186 os can be attempted. The group portrait allows insights and speculations on the rationales and processes behind the movement of the objects, from the point of view of European demand, but also of Middle Eastern availability. The increased presence of artefacts from the Eastern Mediterranean and Central Asia in Second Empire Paris ultimately raises broader issues about the commodification and translocation of material culture from a region caught up in a declining Ottoman Empire called to modernise in the face of expanding European imperialism.

\section{Orientalia at the Musée rétrospectif} in 1865

The Union centrale des beaux-arts appliqués à l'industrie, a body better known under the name it adopted in 1882 of Union centrale des arts décoratifs (UCAD), was created in 1861 by a group of artists, collectors and manufacturers with the view of promoting a French renaissance in the applied arts, along the model offered by the London South Kensington Museum (today the Victoria and Albert Museum), consisting of galleries with a design school and art library. The aim was to sustain the idea of "functional, yet pleasant design" "le beau dans l'utile" - as the motto went. ${ }^{4}$ The ultimate goal was to counteract the hegemony of British manufactured furniture and other wares.

An early initiative was a survey exhibition of decorative arts, presenting contemporary design and crafts alongside historic artworks. The latter were meant to deliver lessons and patterns to draughtsmen and artisans, besides providing useful knowledge for art history. A call was launched in April 1865 inviting the main owners of fine

4 Le Beau dans l'utile. Histoire sommaire de l'Union centrale des beaux-arts appliqués à l'industrie: suivie des rapports $d u$ jury de l'Exposition de 1865 (Paris: Union centrale, 1866). artworks from all major periods (chiefly Antiquity, Middle Ages, Renaissance and Enlightenment) and, less expectedly, from all countries, to participate in the show. The plea argued that so far only objects in museums and public collections had provided patterns to industry, while many more lay in home galleries, hidden from the general public and separated from the crafts sphere. ${ }^{5}$

About 200 amateurs responded positively to the novel initiative - there had been no loan shows in France prior to this. Some 6,700 objects joined the historic section of the exhibition entitled Musée rétrospectif, which lasted from 10 August until 3 December 1865 . Fortunately, catalogue headings exist for each item on display and valuations are available for those properly recorded in the loans register of UCAD (not all were). More importantly, images for many of the exhibits do survive. Views of objects presented at the show were taken by the French photographer Franck (François Alexandre Gobinet de Villecholle; 1816-19o6), prints of which, mounted on card, could be purchased separately or in bound portfolios. A complete set containing 845 plates is preserved at the Victoria and Albert Museum. ${ }^{6}$ Pairs or trios of objects, as well as larger groups, appear frequently in the photographs, meaning that a good proportion, probably one third, of the Musée rétrospectif can be visualised through Franck's photographs. The documentation is not consistent, however, since not all photographed objects can be traced in the exhibition catalogue or in the loans register. Nevertheless, it still has evidence to offer on collecting trends at the time.

5 Union centrale des beaux-arts appliqués à l'industrie, Exposition de 1865. Palais de l'industrie. Musée rétrospectif ... (Paris: Librairie centrale Julien Lemer, libraireéditeur, 1867), vi.

6 François Alexandre Gobinet de Villecholle dit Franck, L'Art ancien: photographies des collections célèbres, Première partie: exposition de l'union centrale des beaux-arts appliqués à l'industrie, Musée rétrospectif (Paris: n.p., [1868?]), in the Prints, Drawings and Paintings department of the Victoria and Albert Museum. Partial sets are at the Bibliothèque de l'InHA and the Bibliothèque nationale de France. 


\subsection{The Armour Effect}

Among the thousands of objects on show, 494 belong, according to the exhibition catalogue, to what would today be termed art from the Middle East, even if they were not necessarily recognised as such at the time. For instance, glasswork from Mamluk Egypt or Syria could be deemed Venetian. Arms and armour provided the highest number (342, about 70 percent) of Middle Eastern exhibits and of these, the largest share (140) corresponded to the weapons presented by the fourth Marquess of Hertford, Richard Seymour-Conway (180o70) (Fig. 3). An eccentric British bachelor, the Marquess had made his home in Paris; born into one of the richest families in Europe, he had inherited large collections that he in turn expanded. His Oriental armoury was his personal acquisition, and a recent one made at a late age. Most of his Eastern arms were purchased at famous sales in Paris, such as the Pourtalès or Morny auctions of $1865 .{ }^{7}$ At a Vernet sale in March 1858 , Seymour-Conway had procured half the stock of Eastern arms on offer, representing 27 pieces out of $46 .^{8}$ Many of the Eastern arms purchased by the Marquess on the Parisian market can be viewed today at the Wallace Collection in London, together with European arms purchased at a later stage. Upon the Marquess' death, in the wake of the Franco-Prussian war and the Paris Commune upheavals, his son Richard Wallace (1818-90) had made bulk acquisitions, before having the entire Hertford holdings and his own collection transferred to Britain in $\mathbf{1 8 7 2}$. By then, the Oriental armoury had expanded to 6oo items. Specimens were assembled for decorative effect and testify to the taste for heavily ornate pieces enriched with gold and gems. Most were of Indian provenance,

7 Guy Francis Laking, Wallace Collection, Oriental Arms and Armour (London: Printed for the Trustees by W. Clowes, 1964), XI.

8 Léa Saint-Raymond, "Le pari des enchères: le lancement de nouveaux marchés artistiques à Paris entre les années 1830 et 1939" (PhD diss., University of Paris-Nanterre, 2018), 151. with some eighteenth- and nineteenth-century Persian and Turkish examples. ${ }^{9}$

Oriental armouries were not rare among European rulers and aristocracy. The tradition of collecting Islamic arms can be traced back to the Middle Ages, when weaponry arrived as war trophies from battlefields in the Holy Land or diplomatic gifts from Middle Eastern rulers. ${ }^{10}$ The colonial expansion into India and North Africa brought its own supply of guns, daggers, helmets, vambraces, shields and shirts of mail. Individual expeditions provided further occasions for procurement. From 1868-69 onwards, adventurous excursions in Central Asia helped the Swiss Islamic art collector Henri Moser (1844-1923) to assemble an extraordinary assortment of pieces that he completed through fifteen years of regular visits to the Hôtel des ventes in Paris, the main auction house in the city, located on Drouot Street. His 1,300 arms and armour were bequeathed to the Bern Historical Museum in 1914. Prior to the donation, Moser had his holdings picturesquely displayed in his mansion in Charlottenfels (Switzerland). Arms were classically arranged in symmetrical trophies hanging on the walls; complete suits of armour were presented on wooden equestrian figures and mannequins properly dressed up (see Chapter 5$),{ }^{11}$ a typical set up of which many other instances are known. The most extravagant one is probably the staging devised by the British expatriate Frederick Stibbert (1838-1906), who had two

The Wallace Collection: Guide to the Armouries (London: Trustees of The Wallace Collection, 1982), 39; Suzanne Higgott, 'The Most Fortunate Man of His Day. Sir Richard Wallace: Connoisseur, Collector \& Philanthropist (London: Wallace Collection and Pallas Athene Books, 2018).

Doris Behrens-Abouseif, Practicing Diplomacy in the Mamluk Sultanate: Gifts and Material Culture in the Medieval Islamic World (London and New York: I.B. Tauris, 2014).

11 Henri Moser, Collection Henri Moser-Charlottenfels: armes et armures orientales (Leipzig: K.W. Hiersemann, 1912), pl. 1; Francine Giese, Mercedes Volait, Ariane Varela Braga, eds., À l'orientale, 101-05. 


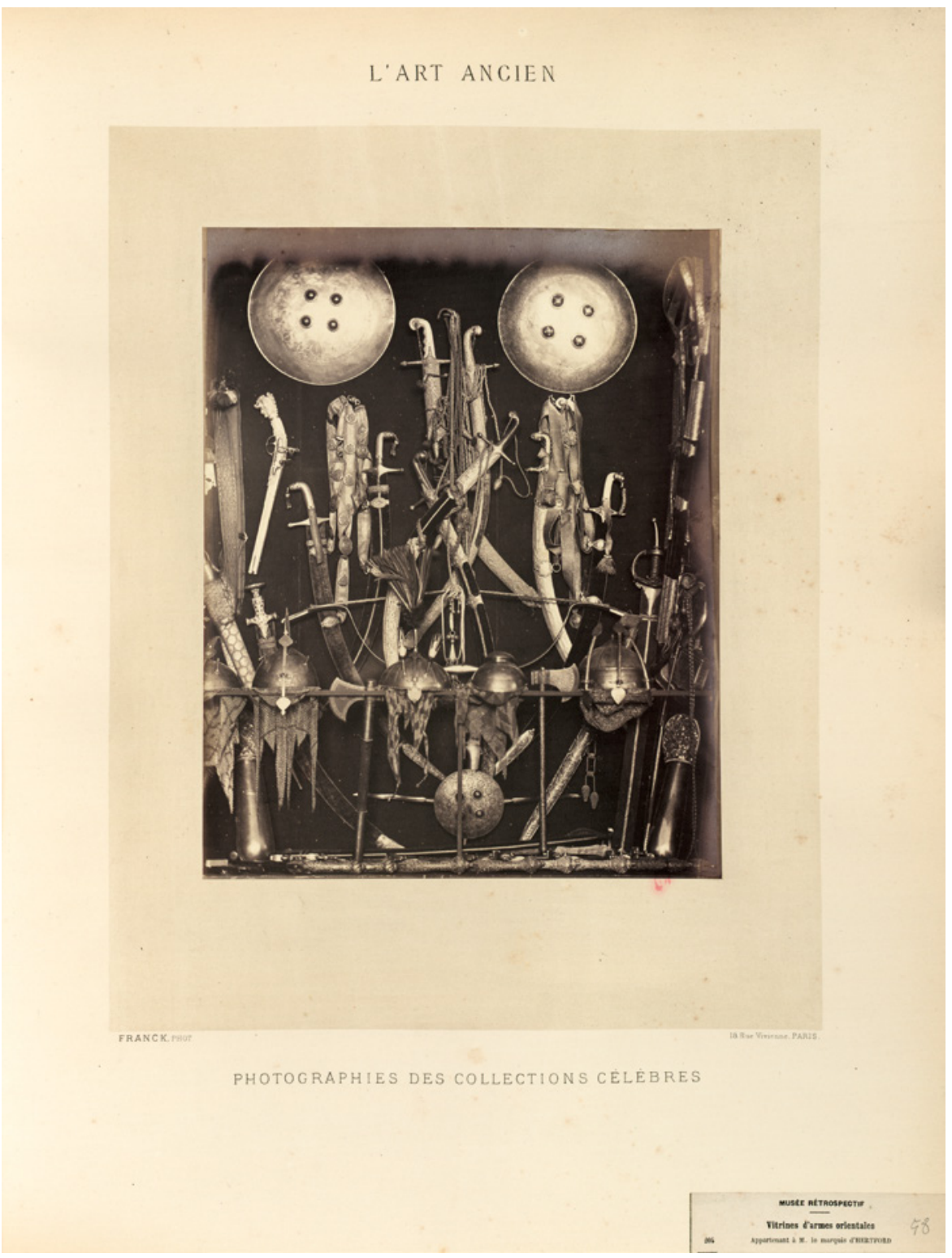

FIGURE 3 Franck, Vitrine d'armes orientales, collection du marquis d'Hertford. Oriental arms lent by the fourth Marquess of Hertford to the 1865 show. Albumen print. $22.7 \times 18.5 \mathrm{~cm}$. Franck, L'Art ancien: photographies des collections célèbres, 1868: Pl. 204 PARIS, BIBLIOTHÈQUE DE L'INHA, FOL EST 752 (1), F. 58

armouries installed in his property in Florence. An elongated hall, with Gothic Revival wall painting, hosted a long cavalcade of knights and infantry wearing European armour, while a second room, walled with white stucco work cast from the Alhambra, presented figures clothed with Eastern military accoutrements. Altogether, Stibbert's collections, both Western and Eastern, amounted to over 16,ooo pieces, mostly purchased after $186 \circ .{ }^{12}$ With their gilding, precious components,

12 On Stibbert, Simona di Marco, Frederick Stibbert (1838-19o6), Vita di un collezionista (Turin/New York: Umberto Allemandi, 2009); Francesco Civita, ed., 
sophisticated mechanisms and "exotic" provenance, arms and armour had become highly fashionable in mid-nineteenth-century European society. The Gothic Revival and the Romantic Movement had awakened an unprecedented curiosity for objects evocative of medieval chivalry. They eventually represented a good part of the collections of the French Emperor Napoleon III himself. They became a way for the new plutocracy represented by the affluent bourgeoisie to advance their status. Lenders of Islamic arms at the 1865 loan exhibition included members of the Rothschild family, the Marquess of Saint-Seine, the historian Achille Jubinal, the Prefect Albert Germeau, as well as dealers (Baur, Berthon and Henry) riding the wave. American collectors followed three decades later and became the major heirs and conveyors of that fashion. ${ }^{13}$

Middle Eastern armour and weaponry were also sought after by artists. The painter Mariano Fortuny y Marsal (1838-74) was a dedicated collector of arms and armour, mostly Oriental. Martial artworks spoke to him: they had the potential to convey history and as such, fired his imagination. In his words, "ancient blades recounted the past better than a book;"14 fights and battles were seen as encapsulating the essence of history. Fortuny partook in the on-going craze for Persian helmets [kulāh khūd], highly elaborated head pieces, still in use in eighteenth- and nineteenth-century Iran (possibly more for parade than battle); he is known to have owned about a dozen different

Islam. Armi e armature dalla collezione di Frederick Stibbert (Florence: Centro Di, 2014).

13 Stuart W. Pyhrr, "American collectors and the formation of the Metropolitan Museum's Collection of Islamic arms and armor," in Islamic Arms and Armor in the MET, ed. David G. Alexander (New York: The Metropolitan Museum of Art, 2015), 3-17.

14

Édouard de Beaumont, "Armes," in Atelier de Fortuny: oeuvre posthume, objets d'art et de curiosité, armes, faïences hispano-moresques, étoffes et broderies, bronzes orientaux, coffrets d'ivoire, etc. ... dont la vente aura lieu les 26 avril et jours suivants [Lugt 35598] (Paris: imprimerie J. Claye, 1875), 71. specimens. ${ }^{15}$ Nor was he the first one to do so. The famous Orientalist artist Jean-Léon Gérôme (1824-1904) is said to have set the trend for artists to collect Middle Eastern curios, ${ }^{16}$ among which were arms. A wall of his studio was covered with martial paraphernalia (Fig. 4); and some feature as props in his Orientalist canvases. His brotherin-law, the art dealer Albert Goupil (1840-84), followed the fashion and had many displayed in the Oriental room he specially arranged in the 188 os for his Islamic collections. ${ }^{17}$

\subsection{Precious and Radiant}

Next in number after weapons at the 1865 show, were ceramics (seventy-six), and in particular the so-called "Persian earthenware" (or faïences persanes in French sources). ${ }^{18}$ Most were in fact Iznik pottery (i.e. Turkish-made), as it was later discovered, ${ }^{19}$ or productions from Damascus; they were generally acquired in Damascus itself, Cairo, Istanbul, or Izmir. A bottle mounted with a silver terminal, loaned by Arabist Charles Schefer (1820$98)$ to the 1865 Musée rétrospectif, and now in the Louvre, ${ }^{20}$ exemplifies how colourful such vessels

15 Carlos G. Navarro, "La historia domesticada. Fortuny y el coleccionismo de antiguëdades," in Fortuny (18381874) ed. Javier Barón (Madrid: Museo del Prado, 2017), 373-425.

16 Alfred Frigoult de Liesville, Coup d'œil général sur l'exposition historique de l'art ancien (palais du Trocadéro) (Paris: Honoré Champion, 1879), 44.

17 Mercedes Volait, "Les intérieurs orientalistes du comte de Saint-Maurice et d'Albert Goupil: des 'Cluny arabe' au Caire et à Paris à la fin du XIX" siècle," in The Period Rooms. Allestimenti storici tra arte, collezionismo $e$ museologia, eds. Sandra Costa, Dominique Poulot, Mercedes Volait (Bologne: Bononia University Press, 2017), 103-14.

18 Julian Raby, "Iznik: the European perspective," in Nurhan Atasoy \& Julian Raby, Iznik: the Pottery of Ottoman Turkey (London: Alexandria Press, 1989), 71-4.

19 Arthur Lane, "The Ottoman pottery of Iznik," Ars Orientalis, no. 2 (1957): 247-81.

20 Bottle mounted with silver terminal, Iznik, $1535^{-1545}$ AD 9142 (long term loan to the Musée du Louvre). The piece was acquired for F 2250 at the Charles Schefer sale in 1898 (lot no. 37) by the dealer Stora, and resold by him the following year to UCAD. Paris, Institut de 


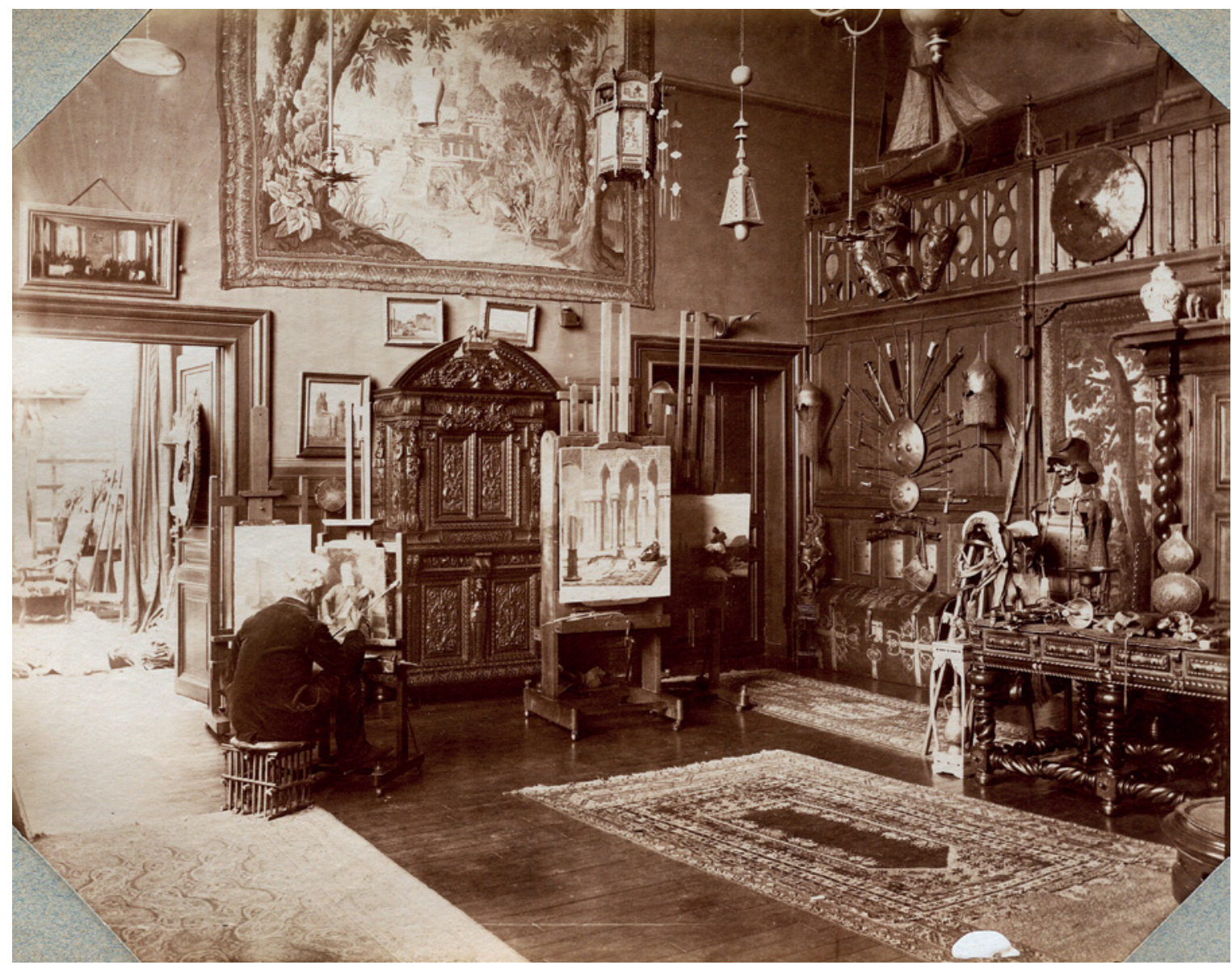

FIGURE 4 Edmond Bénard, Gérôme [Gérôme in his studio], c. 1884 . Albumen print. $20 \times 25 \mathrm{~cm}$. Ateliers d'artistes (1884-94), f. 25 PARIS, BIBLIOTHÈQUE DE L'INHA, 4 PHOT 055

could be: the ware is decorated with turquoise medallions set against a deep cobalt blue ground (Fig. 5).

In sharp contrast with later displays, the show presented very few tiles. There were almost no rugs either as if such goods had not entered yet

France, Ms 5440, Annotated copy, with captioned photographs of some items, of Catalogue des objets d'art et de curiosité, faïences de Perse, de Damas et de Rhodes..., bronzes et porcelaines de la Chine et du Japon ..., bronzes d'art et d'ameublement..., tableaux et dessins anciens et modernes, composant la collection de M. Ch. Schefer, Paris, 8-11 June 1898 [Lugt 56421]; Labrusse, Purs décors, 335 . the world of modern European collecting. Henri Moser believed that the exodus of ancient carpets to the West had been set in motion by the Great Persian famine of $1870-72,{ }^{21}$ but the odyssey of the magnificent Ardabil carpet, now in the Victoria and Albert Museum, tells a different story. The carpet made its way to London after an earthquake in 1873 had damaged the shrine in which it lay. ${ }^{22}$ Broader dynamics were also at play. The motion of lavish Persian rugs to Europe and America resulted both from the greater integration of the Iranian

\footnotetext{
21 Moser, Collection, III.

22 Carey, Persian Art, Ch. 4 passim.
} 


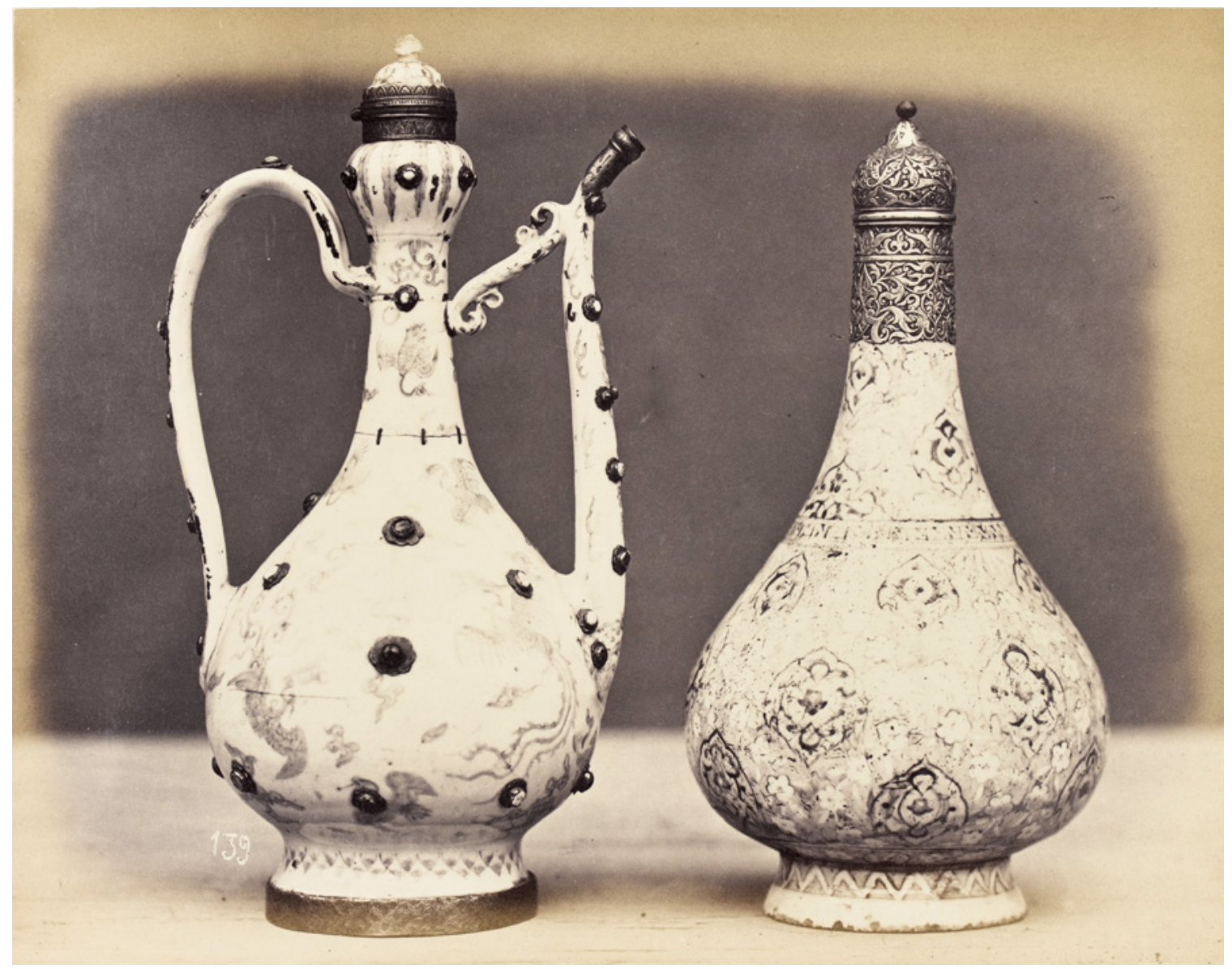

FIGURE 5 Franck, Aiguière et bouteille en faïence persane, collection M. Schefer. Iznik pottery lent by Charles Schefer to the 1865 loan show; the bottle mounted with silver terminal is on the right hand, and is currently on view at the Musée du Louvre. Albumen print. 18.5 × 24 cm. Franck, L'Art ancien: photographies des collections célèbres, 1868: Pl. 139

PARIS, BNF, ESTAMPES ET PHOTOGRAPHIE, LA-100(1-3)-FOL, V. 2

economy into the world capitalist system (implying a "desperate search for a valuable item of export" in the very words of economist Ahmad Seyf, ${ }^{23}$ possibly an exaggerated statement) and an increased demand for luxury consumption from the East in ever-affluent Europe and the United States. In fact, what was truly changing was the direction of export circuits. During the first half of the nineteenth century, rich Persian carpets had mainly been destined for India, Turkey and Russia; as the

23 Ahmad Seyf, "The carpet trade and the economy of Iran, 1870-19o6," Iran 30 (1992): 99-105. century progressed and the purchasing power of the Western middle classes grew, they increasingly travelled west. ${ }^{24}$ The double conjunction of adjustments to the Iranian economy and shifts in global consumption encouraged the development of a carpet industry that was entirely Western looking (and predominantly British-driven, starting with the Ziegler firm established in Tabriz in 1867); almost no one inside Iran could afford such expensive goods.

24 Annette Ittig, "Carpets xi. Qajar Period," Encyclopcedia Iranica IV, no. 8 (1990): 877-83. 
The remaining categories of objects displayed in 1865 at the Musée rétrospectif in bronze, glass, woodwork, miniatures, textiles, and jewellery did not exceed a dozen items each. However, the glass section encompassed some of the most precious and valuable objects on show. One of the Rothschilds from the French branch of the family, the Baron Alphonse (1827-1905), presented two mosque lamps in enamelled glass attributed to the fourteenth century and an "elegant" long-necked flask, enamelled in green, red, and blue, and gilded. ${ }^{25}$ (Fig. 6) The latter was deemed Byzantine, Turkish, or indeed Persian, work at the time; it is now recognized as Egyptian or Syrian, midfourteenth century. ${ }^{26}$ Its Chinese style ornaments reflect the taste for "chinoiserie" in Mamluk culture. The provenance history of the flask, provided by the Met, is instructive, albeit partly erroneous. Its first known owner was a merchant established in Cologne, Peter Leven (1796-1850); at the 1853 public sale of his vast collection of applied arts, the object was acquired by one Prince Soltykoff. This is not Petr Soltykoff (1804-99), as commonly assumed, but his younger brother Alexei Soltykoff (1806-59), a Russian diplomat who had travelled extensively throughout the Middle East and Asia, visiting Persia in 1838, India in 1841 and Egypt almost every winter, before settling in Paris. Many pieces in his collection were gifts received from local dignitaries. ${ }^{27}$ After his untimely death, his brother Petr inherited the precious collection and auctioned part of it in 1861 under his own name, hence the confusion. ${ }^{28}$ The very rare flask was

25 Union centrale des beaux-arts appliqués à l'industrie, Exposition de 1865, 508 (item no. 6047).

26 The bottle is now at the Met, 36.33 .

27 Prince Alexis Soltykoff, Voyage en Perse (Paris: Victor Lecou, 1854); Alfred Darcel, "La collection Soltykoff," in Gazette des beaux-arts, 1861, 169-78, 212-26; Richard R. Walding et al., "The Russian Prince and the Maharajah of Travancore," Journal of Kerala Studies XXXVI (2009): 10-87.

28 Catalogue des objets d'art et de haute curiosité composant la célèbre collection du prince Soltykoff. Objets byzantins et autres, émaux de Limoges, faïences italiennes, faïences françaises de Bernard Palissy, faïences dites de Henri II,



FIGURE 6 Bosredon, Untitled [Enamelled long-necked flask or decanter], c. 1865. The piece is since 1936 at the Metropolitan Museum of Art in New York (36.33). Hand coloured print. $22.2 \times 15.5 \mathrm{~cm}$ PARIS, BIBLIOTHÈQUE NATIONALE DE FRANCE, MANUSCRITS OCCIDENTAUX, FONDS ÉMILE PRISSE D'AVENNES, ART ARABE: VASES, NAF 20443 (2), F. 8

acquired by one of the experts in charge of the sale, Mr. Roussel, for 5,00o francs. It then became the possession of Gustave de Rothschild (18291911), the brother of Alphonse, shortly afterwards, ${ }^{29}$ and ultimately entered the Met in 1936 via the influential dealer Hagop Kevorkian (1872-1962).

bois et ivoires sculptés, orfèvrerie, verrerie de Venise et de Bohême, vitraux anciens, meubles anciens en bois sculpté, objets chinois, russes et indiens, manuscrits, etc., 8 April-1st May 1861 [Lugt (sorted) 26136a] (annotated with prices and purchasers's names).

"Bouteille de fabrication orientale," in Jules Labarte, Histoire des arts industriels au Moyen Age et à l'époque de la Renaissance (Paris: A. Morel, 1864-66): VI: Album, Tome II, f. 62 and pl. 132. 


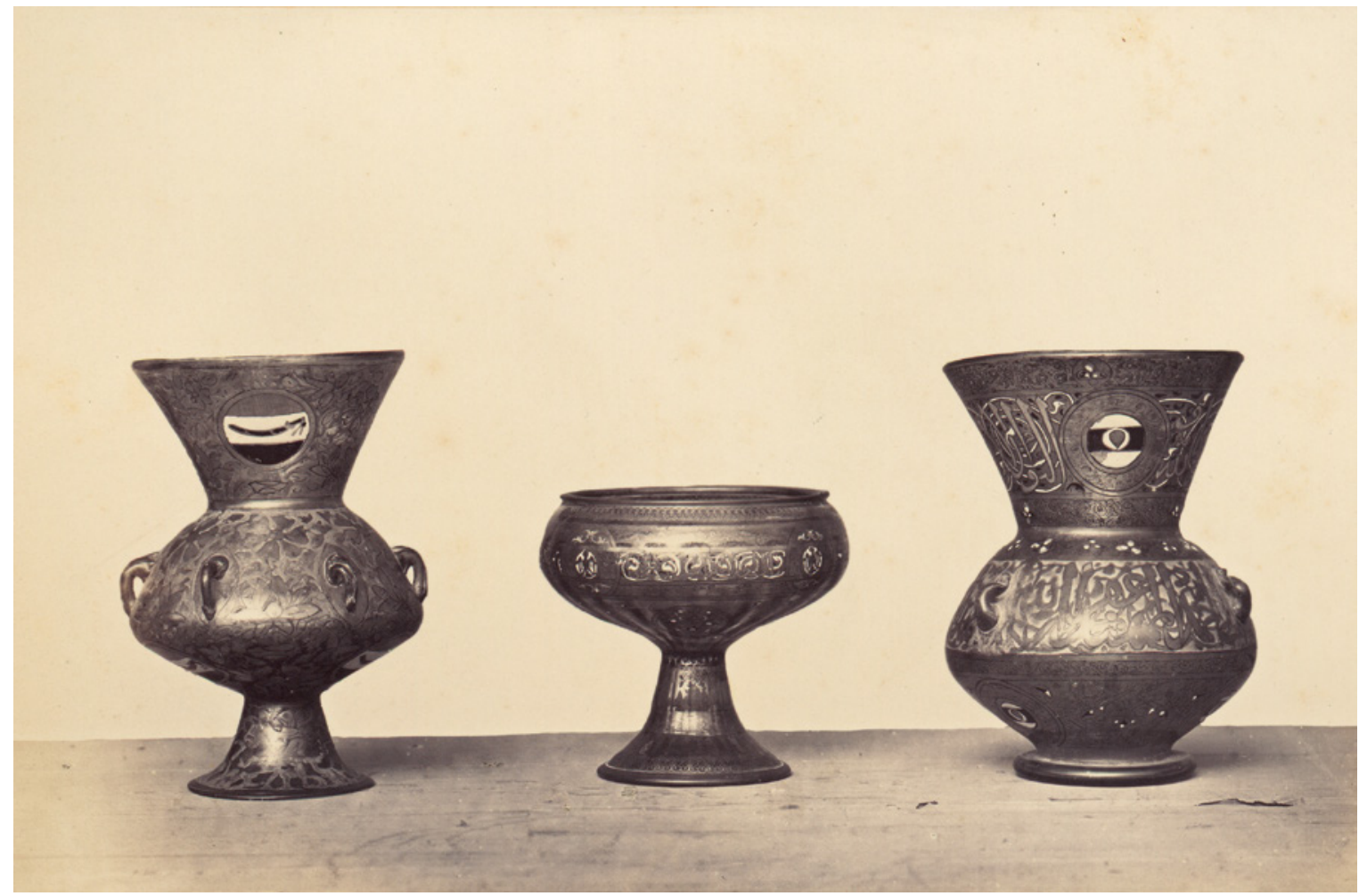

FIGURE 7 Franck, Lampe et coupe arabe, collection Schefer. Lamp and bowl from the Schefer collection exhibited in Paris in 1865 . Mounted albumen print. $15.3 \times 24 \mathrm{~cm}$. Franck, L'Art ancien: photographies des collections célèbres, 1868 : Pl. $25^{\circ}$

PARIS, BIBLIOTHÈQUE DE L'INHA, FOL EST 752 (2), F. 7

The artefact thus belonged to the type of precious Islamic objects that had been in Europe for some time ${ }^{30}$ before beginning to move again from one country to another.

The values of the three Rothschild works of glass given in the ledger of loans to the Musée rétrospectif in 1865 were 6 ,ooo francs for each lamp, and 5 ,ooo francs for the flask. There is no straightforward way to calculate what these values are worth today, but considering that the pound sterling equated 25 francs at the time, 5,000 francs represented $£ 200$, not a small amount when related to

For an assessment of the early presence of Islamic objects in Europe, Gwenaelle Fellinger, "Commerce de l'art et échanges d'objets au Moyen Âge en Méditerranée: le point sur la question," in Espaces et réseaux en Méditerranée, eds. Damien Coulon, Christophe Picard and Dominique Valérian, La configuration des réseaux (Paris: Bouchène, 2007), I: 237-52. the value reached by other Islamic pieces at the time on the European market, as we shall see. The price of 5,000 francs stated for the flask evidences that, while declarative, insurance values did reflect market prices, as the item had been acquired for that very amount a few years earlier. The figures provided are significant in relation to one another: an enamelled mosque lamp was priced six times as much as a Hispano-Moorish vase (1,00o francs) and could approach the value of a set of $3^{1} \mathrm{arms}$ (7,99o francs). ${ }^{31}$

Other glass items were lent by Charles Schefer (Fig. 7). One was a late Ayyubid or early Mamluk bowl with an eagle emblem (Fig. 8), the other a

31 Paris, Archives du musée des Arts décoratifs, A1/69-70, Exposition rétrospective de 1865 . Enregistrement des objets confiés au Musée rétrospectif. For some reason, the artefact was declared by Alphonse, not Gustave. 


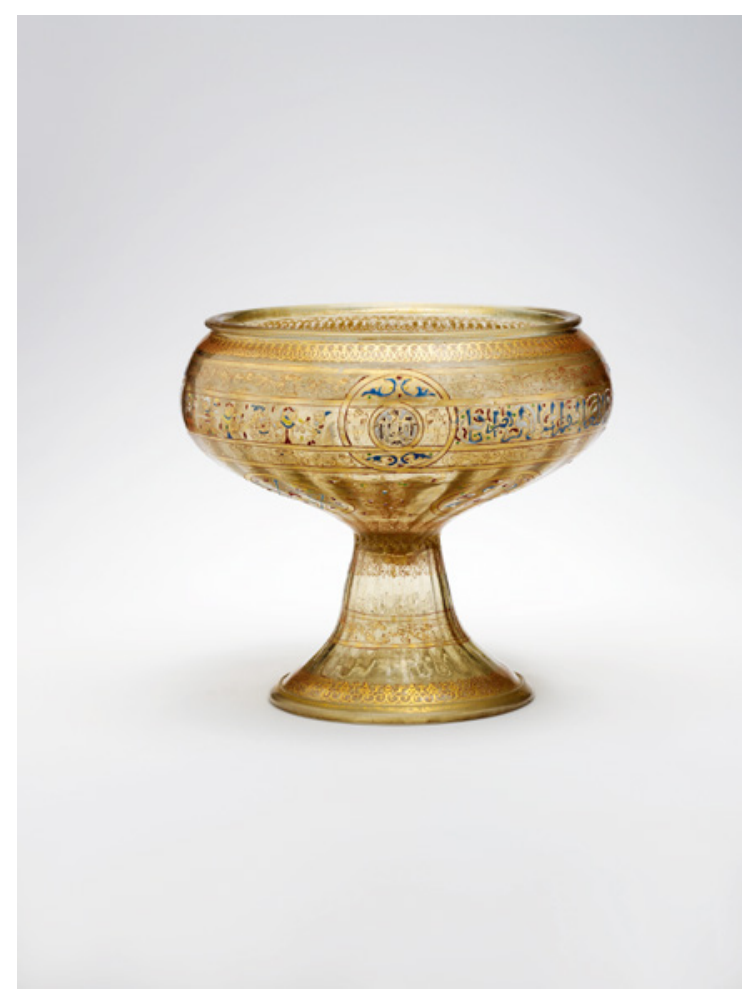

FIGURE 8 Enamelled footed bowl with eagle emblem, probably Syria, mid-thirteenth century. Glass, stained, enamelled and gilded. $18.3 \times 19.7 \mathrm{~cm}$ NEW YORK, METROPOLITAN MUSEUM OF ART (SINCE 1891), 91.1.1538

mosque lamp dated c. 1325 (no value was declared for either of them). Both are today star objects at the Met. ${ }^{32}$ Schefer sold the two glass works during his lifetime ${ }^{33}$ to an American silversmith, Edward C. Moore, who in turn bequeathed them to the Met in $1891 .^{34}$ At Schefer's death in 1898 , his collection of curios still numbered 200 firstrate objects, including early Mamluk metalwork. Gilded or silvered metalwork was particularly sought after by early Islamic art collectors. From

32 The footed bowl is 91.1.1538; the mosque lamp is 91.1.1534.

33 Catalogue Schefer, 1898 (annotated copy).

34 Little is known on Moore's vast Islamic art collection, apart that it was assembled for pattern inspiration: see Elizabeth L. Kerr Fish, "Edward C. Moore and Tiffany Islamic-Style Silver, c. 1867-1889," Studies in the Decorative Arts 6, no. 2 (Spring-Summer 1999): 42-63.
Gustave de Rothschild, Franck photographed, besides glass artefacts, two wondrous brass candlesticks inlaid with silver and gold, one of which had reputedly been part of the estate of the Mamluk Sultan al-Nasir Muhammad ibn Qalawun (d. 1341) in Cairo, as suggested by the caption of a plate in Prisse d'Avennes's L'Art arabe depicting the same object. $^{35}$ (Fig. 9) Prisse's attribution is possibly based on the registers of confronted birds decorating the candlestick's base, the duck being the emblem of Sultan Qalawun.

Nielloed silverware was also much praised. Both one of the Rothschilds and the French aristocrat Gaston de Saint-Maurice (1831-1905) presented ewers made of zinc alloy with silver inlay, attributed then to "Persian, sixteenth century," and identified today as Bidri wares produced in eighteenth- or nineteenth-century India. ${ }^{36}$

\subsection{Demand and Availability}

The biography of individual collectors provides clues to map, in time and space, the process of procurement. The bulk of Charles Schefer's works of art from the Middle East was most probably secured during his time as interpreter of Eastern languages in the French diplomatic service from 1843 to 1857 . Trained since a young age to be a dragoman [from the Arabic turjumān, translator], he was successively posted in Beirut (1843), Jerusalem (1844-45), Izmir (1845-47), Alexandria (1847-49) and Istanbul (1850-57), before being offered the Chair of Persian language at the School of Oriental languages in Paris. ${ }^{37}$ His priceless bowl with an eagle emblem was published in 1859 as an artefact

35 Franck, L'Art ancien, pl. 501; Émile Prisse d'Avennes, L'Art arabe d'après les monuments du Caire depuis le VII $^{\mathrm{e}}$ siècle jusqu'à la fin du XVIII ${ }^{\mathrm{e}}$ (Paris: Morel, $1869^{-}$ 77), 282-83 and pl. CLXIX for a polychrome image of the candlestick. The two pieces are not recorded in the catalogue of the $1_{86}$ Musée rétrospectif.

36 A typical object in this group is a flask in the British Museum, 1878, 1230.76o.

37 Auguste Bouché-Leclercq, "Notice sur la vie et les travaux de L. Charles Schefer," Comptes rendus des séances de l'Académie des Inscriptions et des BellesLettres 43, no. 6 (1899): 627-68 (634). 


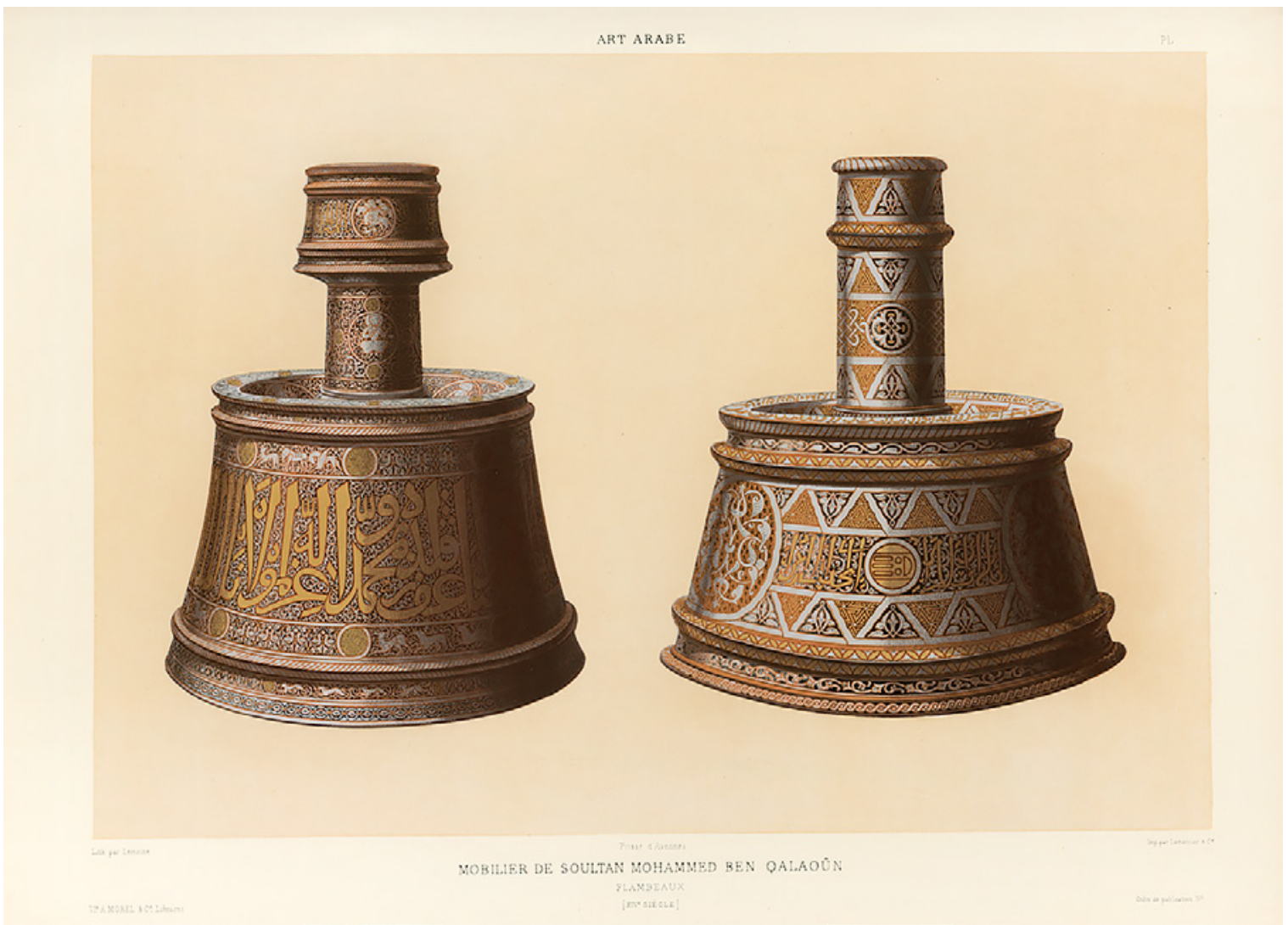

Figure 9 Émile Prisse d'Avennes, Mobilier du Soultan Mohammed Ben Qalaoûn. Metalwork from the estate of Sultan al-Nasir Muhammad ibn Qalawun. The candlestick on the left, at the time in the collection of Gustave de Rothschild, can be related to metalwork from Mosul. Chromolithograph ÉMILE PRISSE D'AVENNES, L'ART ARABE, 1869-77, III: PL. CLXIX

bought in Damascus at a barber's shop, ${ }^{38}$ possibly during his visit to the city in $1844 .{ }^{39}$ The deal discloses familiarity with the region and ease with its dialects and people; while the date of its published print highlights an early acquisition. Another of Schefer's collectibles - the Ottoman gem-set Chinese porcelain ewer illustrated in Fig. $5^{-}$is reported to have been obtained in Damascus in 186 o. $^{40}$

38 Adalbert de Beaumont, Eugène Collinot, Recueil de dessins pour l'art et l'industrie (Paris: Delattre, 1859), pl. 196.

39 Gaston Schefer, La Jeunesse d'un orientaliste, Charles Schefer, 1840-1856 (Paris: H. Leclerc, 1913), 21.

40 Les Collections célèbres d'œuvres d'art dessinées et gravées d'après les originaux par Edouard Lièvre (Paris: Goupil, 1866), pl. 57 .
Travellers' accounts give further hints. Henri Moser recalled that sword-blades could be obtained in Central Asia in exchange for vodka. ${ }^{41}$ The narrative of the years spent out East by the Dutch aristocrat Baron Lycklama (1837-1900) in 1865-68 features comments on purchases made on the spot. The dozen or so weapons he brought back came partly from Persia (Tehran, Isfahan, Tiflis and Sulaymaniyah) and partly from Aleppo and Damascus. ${ }^{42}$ He acknowledged buying modern swords and daggers in the Syrian capital in 1868 ,

\footnotetext{
41 Moser, Collection Moser, IV.

42 Cannes, Archives municipales, $2 \mathrm{R} 44$, Catalogue du Musée Lycklama, 27 June 1887; Ernest Massenot, Musée de M. le chevalier T. M. Lycklama à Nijeholt: notice descriptive provisoire: musée oriental (Bruxelles: Leemans \& Vanberendonck, 1871).
} 
because "although the renowned scimitars were no longer produced in Damascus, one could still find blades of good quality" that "could decently stand comparison with [his] Persian collection." ${ }^{43}$ His Persian and Syrian armoury, among a collection of 700 artefacts bought during his extended tour, and installed in France in 1877, is held today by the Musée de la Castre in Cannes (France). ${ }^{44}$

Marks on objects can point to manifest provenance. Arms originating from the Ottoman arsenal generally held a seal, called a tamga in Turkish, incised into the iron surfaces. (Fig. 10) Otherwise known as an "arsenal mark," it presents a sign close to the letter Y flanked by two vertical lines, the whole being enclosed in a circle. Two of the helmets owned by Jean-Léon Gérôme, now in The Walters Art Museum (Baltimore, US), bear this arsenal mark. ${ }^{45}$ Similarly do the hundred pieces of Islamic armour possessed by the Met alone. ${ }^{46}$ Good opportunities to procure Oriental arms (as well as European ones) from spoils of war were offered by cyclic disposals of surplus stock from the Ottoman arsenal lodged since 1453 in the former church of St. Irene (within the Imperial Palace precinct). The collections won from the Persians, Mamluks or Christian knights had been reorganised in 1726 as a dār al-asliha or maison d'armes. Some of the arsenal's holdings were looted by the Janissaries around 1800. Objects associated with

43 My translation from Voyage en Russie, au Caucase et en Perse, dans la Mésopotamie, le Kurdistan, la Syrie, la Palestine et la Turquie exécuté pendant les années 1866, 1867 et 1868 par T. M. Chevalier Lycklama a Nijeholt (Paris: Arthus Bertrand, 1872-75), Tome 4, 548: "Damas ne fabrique plus ces cimeterres jadis si renommés; cependant ses lames sont encore estimées des connaisseurs, et je ne me suis pas refusé l'achat d'une demi-douzaine de sabres et de poignards qui font encore bonne figure auprès de ma collection d'armes persanes."

44 Joseph Billiet, "La collection Lycklama au Musée de Cannes," Gazette des beaux-arts LXXIII (July 1931): 321-40.

45 Baltimore (US), The Walters Art Museum, Late medieval turban Helmet, fifteenth century, 51.70 and 51.74. See also Marianna Shreve Simpson, "A Gallant Era': Henry Walters, Islamic Art, and the Kelekian Connection," Ars Orientalis 30 (2000): 91-112.

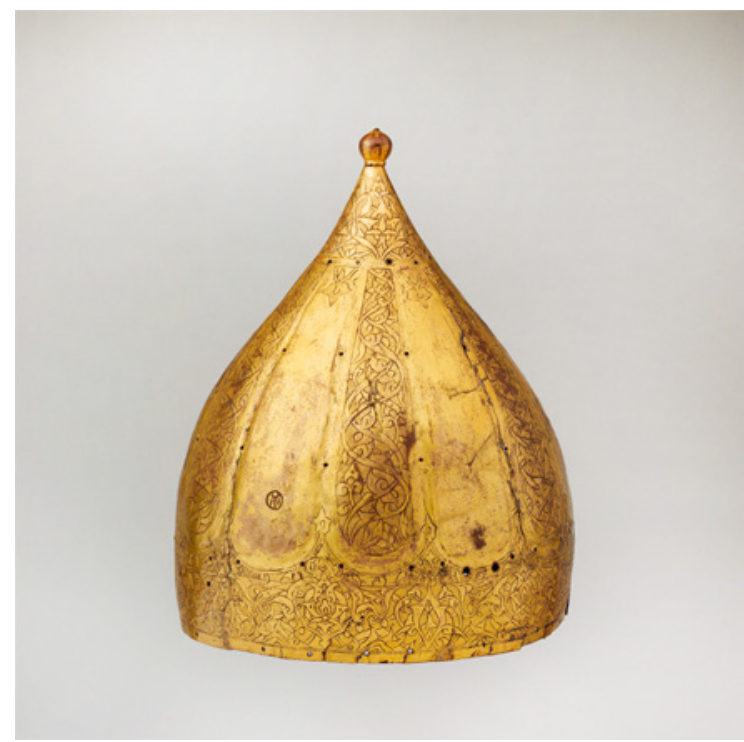

FIGURE 10 Tamga on the central part of a Turkish Helmet, late fifteenth-century NEW YORK, METROPOLITAN MUSEUM OF ART, 04.3.212, FORMERLY IN THE COLLECTION OF CHARLES MAURICE CAMILLE DE TALLEYRAND-PÉRIGORD, DUC DE DINO, PARIS

these militias were removed from St. Irene after the abolition of the corps in $1826 .{ }^{47}$ A well-informed scholar dates a major clearance of old stock to 1852 , and considers that this event was instrumental in the formation of private collections of Islamic arms and engraved metalwork in Europe. ${ }^{48}$ A previous large dispersion of ancient spoils of Christian and Persian arms and armour stored in St. Irene is known to have taken place around 1839. Nevertheless, significant series of objects, among which were the most ornamented pieces, remained in place. A weaponry museum was rearranged there in the late 1870 ; and, later, what was left of the collection was ultimately transferred to Istanbul's Military museum. ${ }^{49}$ (Fig. 11 \& 12)

Stuart W. Pyhrr, "European Armor from the Imperial Ottoman Arsenal," Metropolitan Museum Journal 24 (1989): 85-116.

48 Liesville, Coup d'œil, 44.

49 Pyhrr, 1989. 


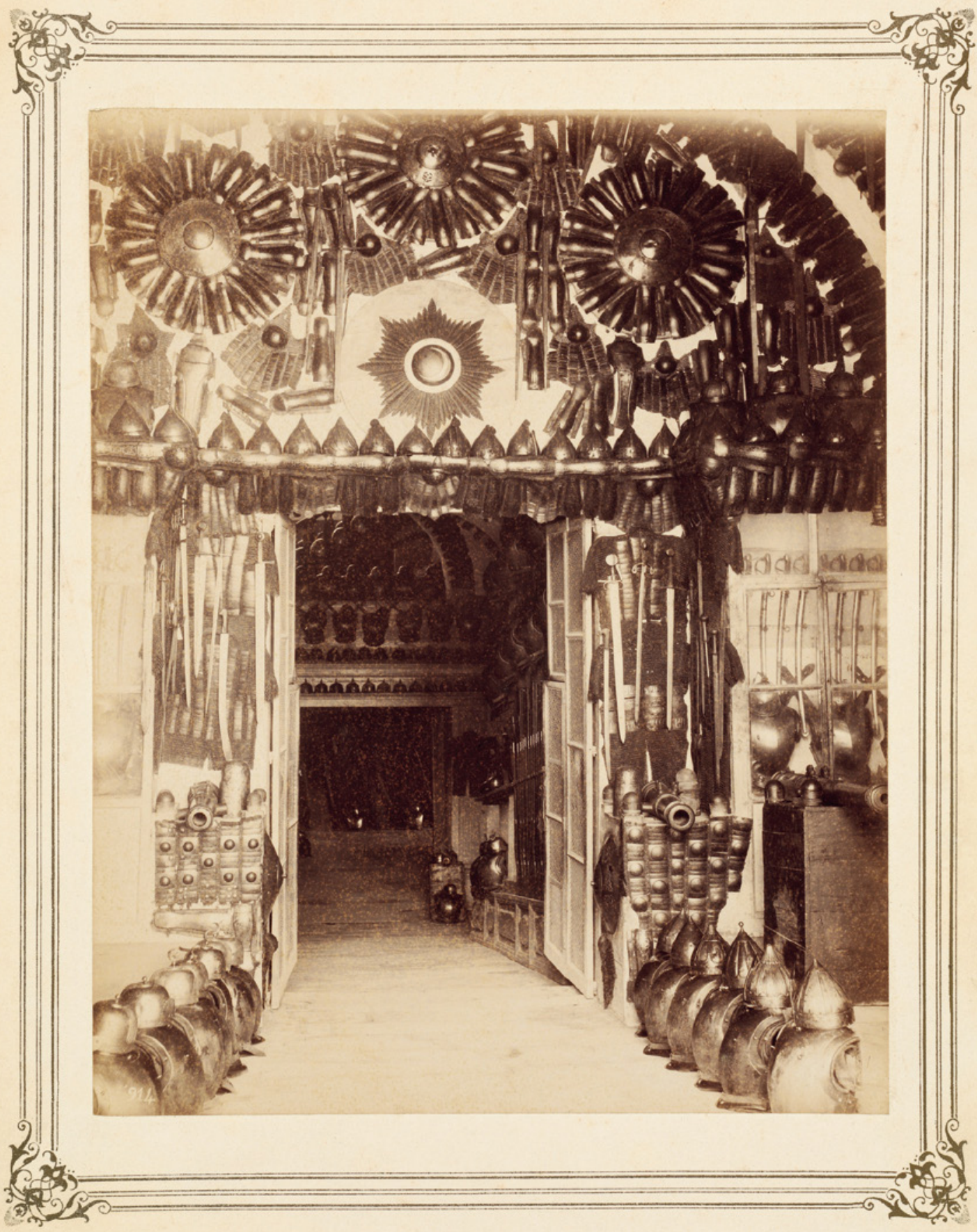

FIGURE 11 Abdullah Frères, Untitled [Entrance of Saint Irene, the Ottoman arsenal in Istanbul], before 1891. Mounted albumen print. $45.1 \times 33 \mathrm{~cm}$. Vues de Sainte-Irène, Constantinople, 1891: Pl. 3 NEW YORK, METROPOLITAN MUSEUM OF ART, 2016.649 


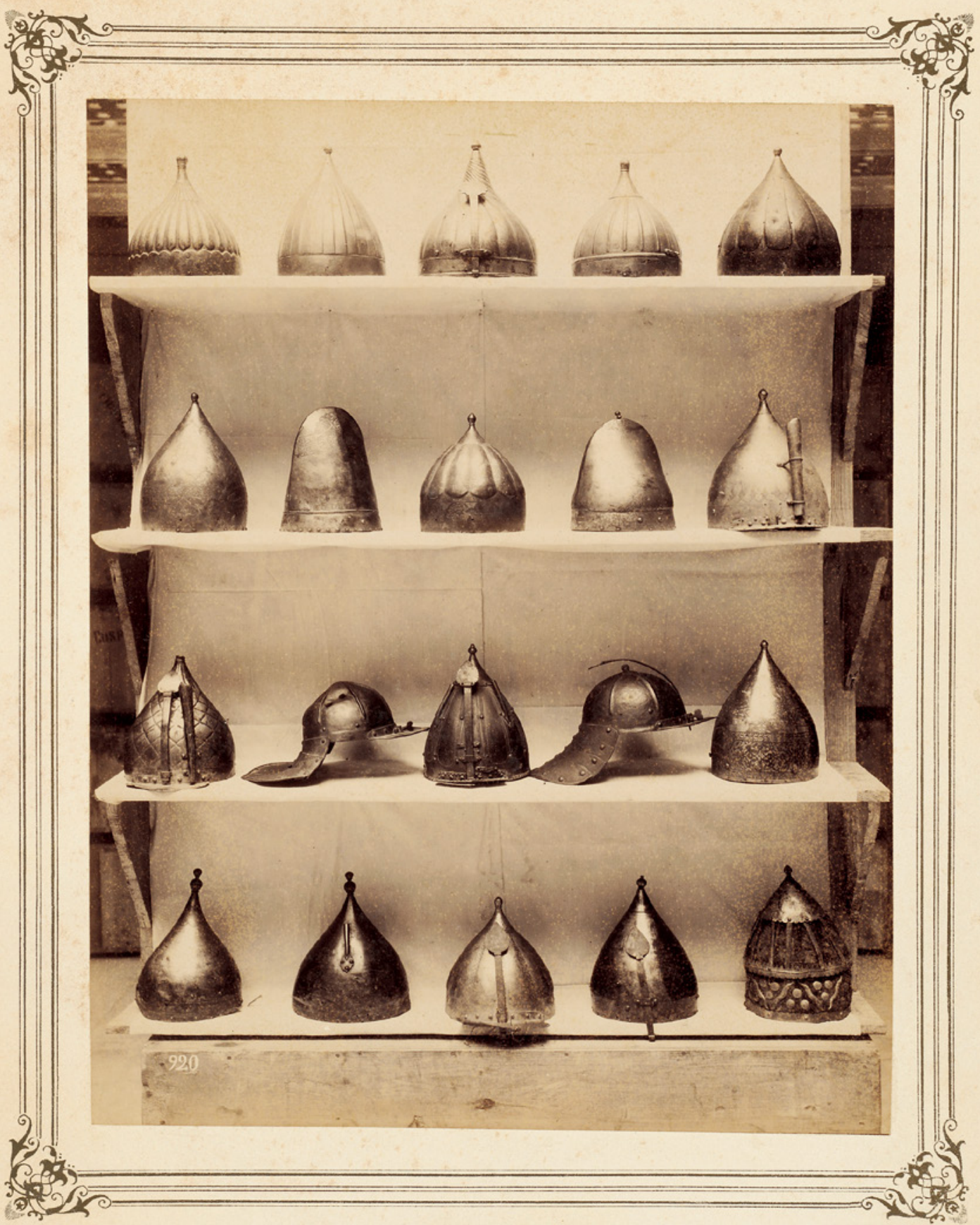

FIGURE 12 Abdullah Frères, Untitled [Helmets on shelves at Saint Irene], before 1891. Mounted albumen print. $45.1 \times 33 \mathrm{~cm}$. Vues de Sainte-Irène, Constantinople, 1891: $\mathrm{Pl} .34$

NEW YORK, METROPOLITAN MUSEUM OF ART, 2016.649 
The Islamic objects presented at the Musée rétrospectif by a more modest collector, Gustave de Beaucorps (1824-19o6), help to narrow the temporal and geographic frames of specific acquisitions. Little is known about Beaucorps, apart from that he earned his living as a Treasury official in the French administration and was an early practitioner of photography. Of aristocratic stock but diminished wealth (the family's revenues had disintegrated during the French Revolution), he is remembered as a passionate and highlycultured amateur. ${ }^{50}$ The collecting history of his Islamic artworks is comparatively less obscure. It is a condensed one, as the collection was formed and dispersed within less than ten years. An early supporter of UCAD, ${ }^{51}$ Beaucorps lent twenty-four pieces to the 1865 Musée rétrospectif. Many were subsequently published in the illustrated journal L'Art pour tous, ${ }^{52}$ and most auctioned in April 1868. In the introduction to the sale catalogue, Beaucorps highlights the direct Middle Eastern provenance of his pieces, stating that they were not acquired at European dealers or auction houses, but during several journeys across the Middle East. ${ }^{53}$ There is no reason to question the statement, as Beaucorps is known to have been touring the Mediterranean from $185^{8}$ to 1861 , with stops in Algeria (1859), Morocco, Jerusalem, Damascus, Istanbul (186o) and Cairo (1861). ${ }^{54}$

50 Charles de Beaucorps, Famille de Beaucorps: notes historiques et biographiques (Saint-Brieuc: n.p., 1928), 117-18.

51 Le Beau dans l'utile, 3 o.

$5^{2}$ L'Art pour tous was a new encyclopaedia of industrial and applied arts meant to educate the general public; Beaucorps objects feature in issues no. 179, 185, 190, 193 (1867), no. 212 (1868), no. 237 (1869) and no. 304, 321, 324 (1873).

53 Catalogue des objets orientaux, faïences de Perse et Hispano-Mauresques; armes orientales ... composant la collection de M. G. de B, 16-17 April 1868 [Lugt 30431]. While Beaucorps is named only by his initials in the title of the catalogue, he can be easily identified as the catalogue refers to objects published in L'Art pour tous under his full name.

54 Marianne Thauré, Michel Rérolle, Yves Lebrun, eds., Gustave de Beaucorps, 1825-1906. Calotypes "l'appel de
An annotated copy of the Beaucorps' sale catalogue specifies the hammer price for each item. ${ }^{55}$ The object that made the highest price (3,00o francs) was a large footed basin labelled Persian (item no. 1). The caption referred to its illustration in a survey on world ceramics, ${ }^{56}$ and the piece can thus be recognised as one photographed at the 1865 show, ${ }^{57}$ when it had been priced at a mere third of its sale price (1,00o francs). (Fig. 13) Its design featured composite lotuses and saz leaves, prunus flowers, bands of tulips and lobed medallions on light ground. The colour scheme was detailed in the sale catalogue as composed of cobalt, green, turquoise, and manganese on a white ground. An almost identical specimen in design, and seemingly colour, identified as midsixteenth-century Iznik, is at the British Museum; its radiant white background contributes to the distinctiveness of this vessel, which was originally inspired by Chinese wares. ${ }^{58}$ When auctioned, Beaucorps' basin was deemed the finest known example of such productions. That its value could triple in less than three years also testifies to a new appreciation for such type of object. Next in line price-wise was a gilded helmet (item no. $5^{2}$; hammer prices 1,000 francs; valued at 600 francs in the loans register of 1865), with a lion and inscriptions engraved in lobed medallions (Fig. 14). An ivory (or bone?) inlaid casket in ebony, dated to the sixteenth century, possibly of Indian provenance (item no. 111), reached 800 francs.

l'Orient", 1858-1861 (Poitiers: Art Conseil Elysées, Neuilly et les Musées de Saintes et de Poitiers, 1992).

55 London, Research Centre of the National Gallery, French Armour Sales, vol. 32 (1868-1869). The minutes of the sale, sadly, have not survived.

56 Albert Jacquemart, Les Merveilles de la céramique, ou L'art de façonner et décorer les vases en terre cuite, faïence, grès et porcelaine depuis les temps antiques jusqu'à nos jours (Paris: Hachette, 1868), Part I: 243-44.

57 Franck, L'Art ancien, pl. 211.

$5^{8}$ Footed basin with a diameter of $42 \mathrm{~cm}$, previously in the Godman collection, British Museum, G. 66 (on display). 


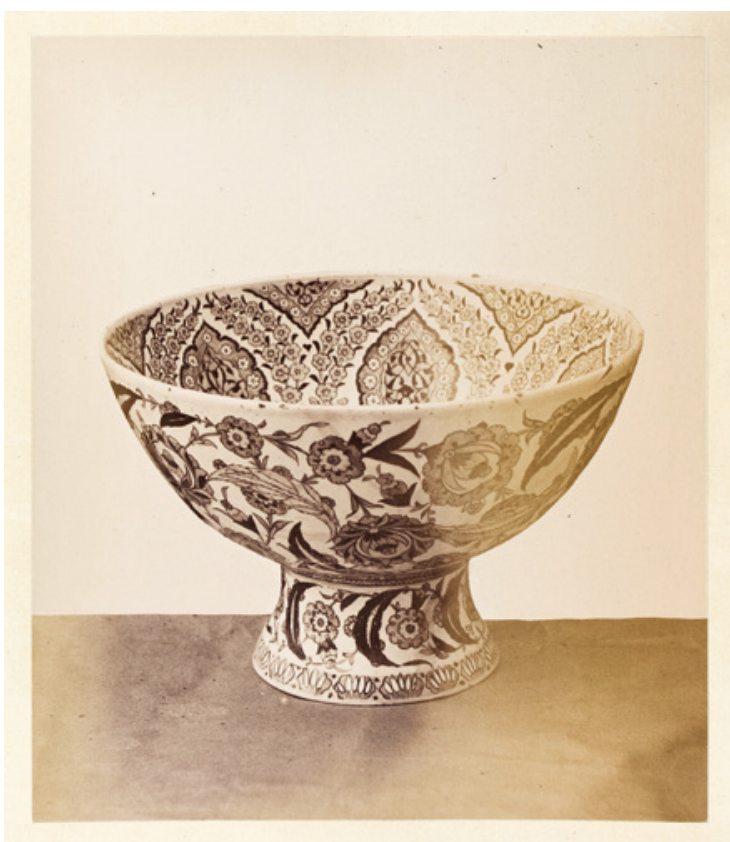

FIGURE 13 Franck, Vasque en faience de Perse, collection de Beaucorps, 1868 . A very similar mid-sixteenth-century Iznik basin is currently on view at the British Museum in London, G. 66. Mounted albumen print. $24 \times 21 \mathrm{~cm}$. Franck, L'Art ancien: photographies des collections célèbres, 1868: Pl. 211 BNF, ESTAMPES ET PHOTOGRAPHIE, LA100(1-3)-FOL, VOL. 2

All other items did not exceed 500 francs per piece. A silver inlaid candlestick "of minute execution and excellent condition" (item no. 94) reached 400 francs (against a declared value of 250 francs in 1865). A large rectangular "Persian" tile of unusual size (item no. 39) made 400 francs, while it had been valued at 60 francs in 1865 . The sixteenth-century Iznik tile can be seen today in the collections of the Musée des Beaux-Arts in Lyons; its dimensions $(43 \times 32.3 \mathrm{~cm})$ are indeed uncommon. ${ }^{59}$ According to the catalogue of the 1865 Musée rétrospectif, it had been part of a shop in Cairo. Its composition was published in L'Art pour tous as a pattern to be used for wall paper. ${ }^{60}$ (Fig. 15) Also auctioned, for 40 francs, at the same sale, was a "wooden coffered ceiling from a fifteenth-century mosque" (no. 116, Plafond de mosquée du $X V^{e}$ siècle, en bois, à compartiments), equally of Cairene provenance. At a second sale in 1869, Beaucorps also disposed of two ewers and rugs brought from Izmir. ${ }^{61}$

A few of his pieces do not appear in either sale. This is the case for four small wooden panels and a metal object; each featured in the 1865 exhibition catalogue, as photographed by Franck at the Musée rétrospectif and published in L'Art pour tous in 1867 . The panels were carved pieces coming from a minbar (pulpit) offered in 1296 by Sultan Lajin to the Mosque of Ibn Tulun in Cairo. ${ }^{62}$ (Fig. 16) As we shall see, more of these intricate polygons reached Paris two years later. Beaucorps had also kept for himself a recognisable Safavid engraved brass ewer, mistaken at the time for an "Indian teapot." (Fig. 17) Its curved spout was inspired by Chinese shapes; it defined a genre of objects that had spread over Persia and beyond in the early seventeenth century, with the earliest known piece recorded in this group dated $1602 .{ }^{63}$ All together these pieces represented remarkable artworks, of what is often referred to as "museumquality" by curators and collectors alike.

6o "Carreau de faïence émaillée, art persan moderne, XVII ${ }^{\mathrm{e}}$ siècle," L'Art pour tous, no. 190, 15 November 1867, 758, item no. 1731 .

$61 \quad$ Objets arabes, Koptes, Koufiques et persans, appartenant en partie à $M$. le Dr $M^{* * *}[$ Meymar $]$ et à $M M$ des Essarts, Henry et de Beaucorps, 8 and 9 January 1869 [Lugt 30875].

62 "Panneaux de bois sculpté, fragment d'une mosquée," L'Art pour tous, no. 193, 1 December 1867, 772, items no. 1766-69.

63 “Théière en cuivre jaune gravé, anse supérieure servant d'orifice à couvercle, et bec en $\mathrm{S}$, bordures, médaillons et inscriptions," no. 5893 of the 1865 Exhibition catalogue; Franck, Théière orientale en cuivre gravé, collection M. de Beaucorps, L'Art ancien, pl. 20o; "Théière en cuivre doré, Art oriental, XVI e siècle," L'Art pour tous, 3о May 1867, no. 179, 715, item no. 1626; v\&A, 458-1876. 
$7^{*}$ Année.

XVI SIÈCLE. - ART PERSAN ANGIEN.

COLLECTIOX DE M. DE BEAUCORPS.
L'AB'T POUR TOUS.

$N^{\circ} 185$.

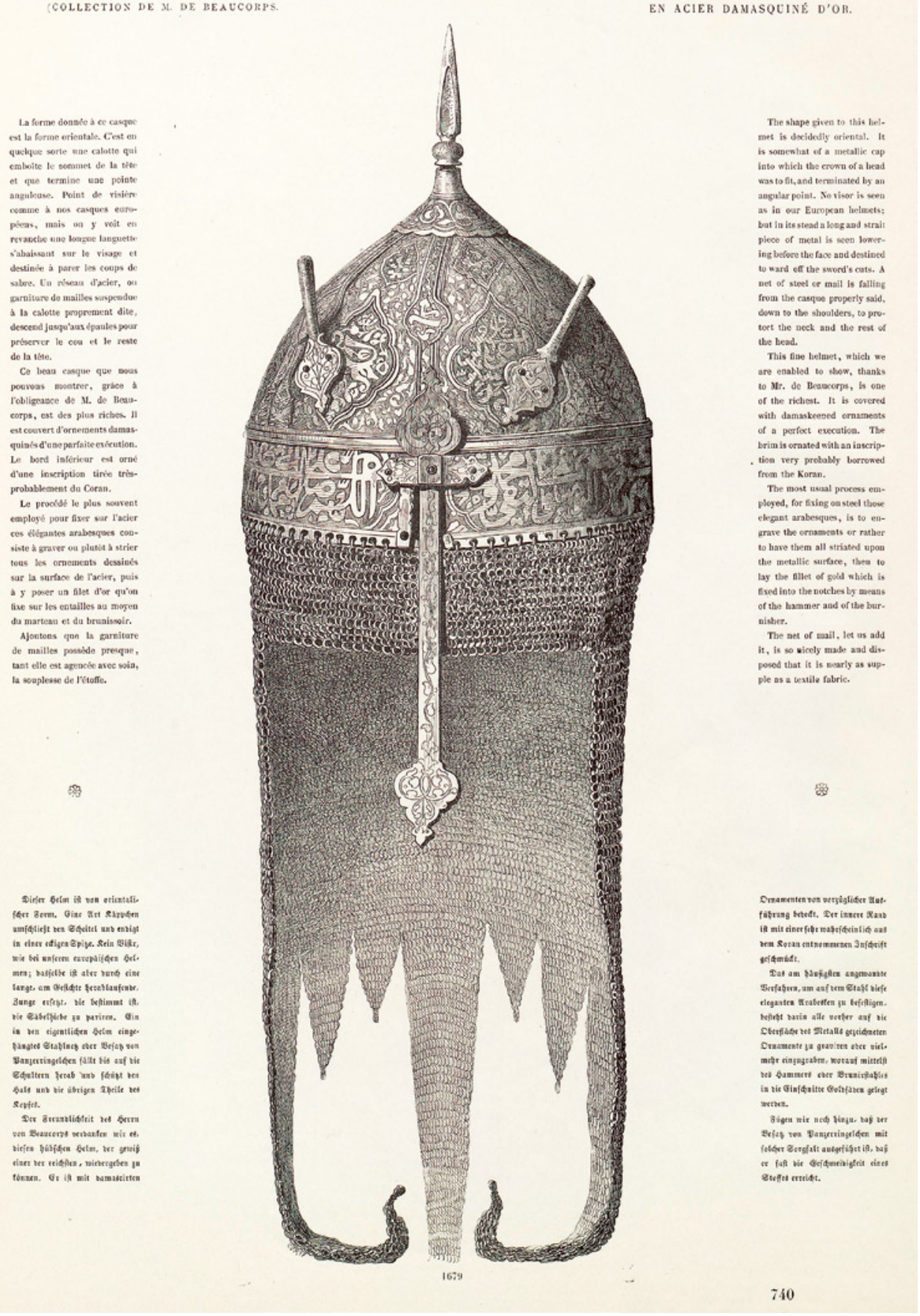

FIGURE 14 Casque à timbre arrondi en acier damasquiné d'or, 1867. [Persian gilded helmet]. While deemed at the time sixteenth-century Persian metalwork, the piece is in all likelihood more recent (current location unknown) L'ART POUR TOUS, 31 AUGUST 1867, NO. 185, P. 740, ITEM NO. 1679 


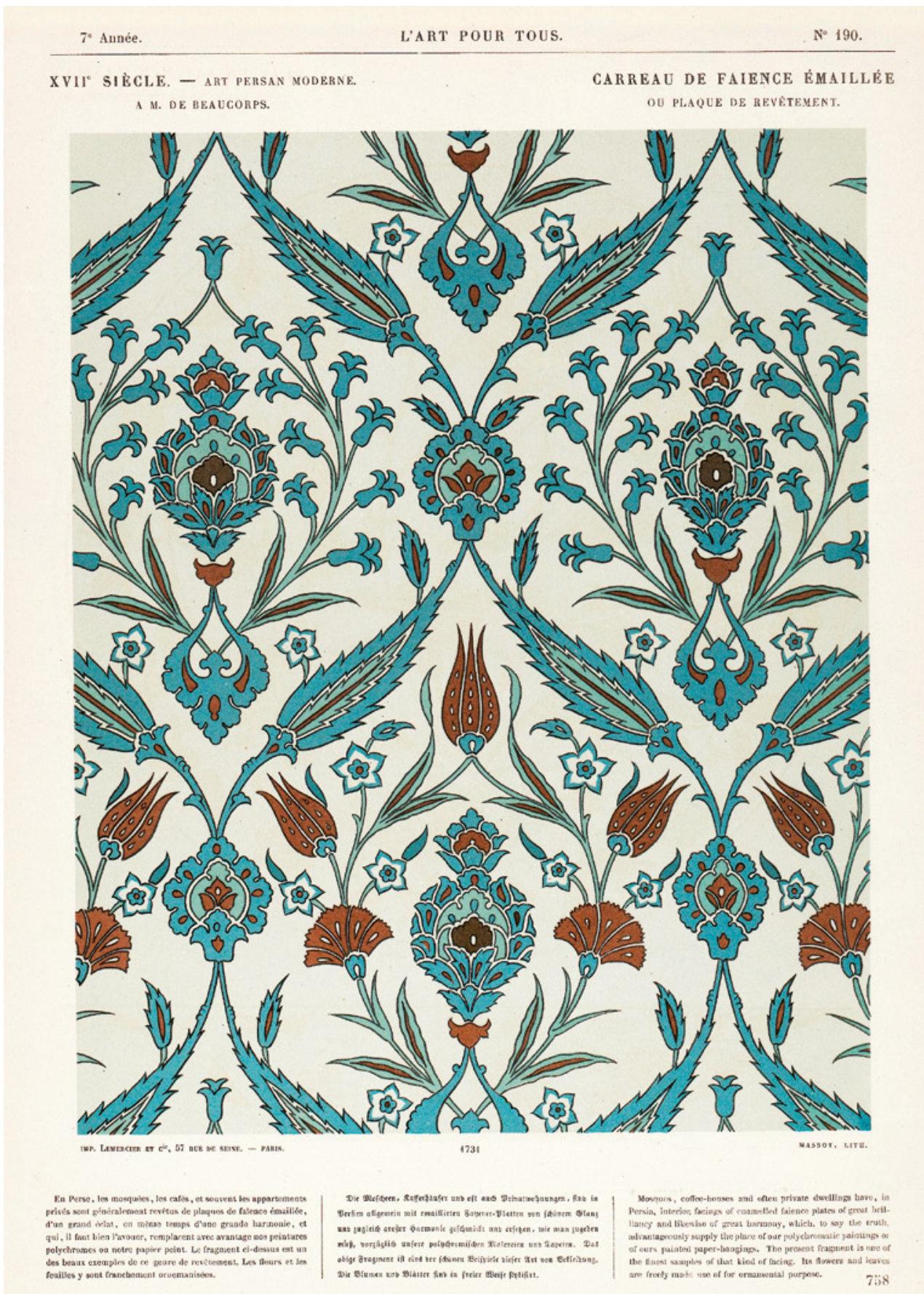

FIGURE 15 Carreau de faïence émaillé, art persan moderne, collection de Beaucorps. The illustration expands on the pattern of Beaucorps' Iznik tile, now in Lyons, Musée des Beaux-Arts, D $470(43 \times 32.3 \mathrm{~cm})$. In 1865 , the piece was labelled as coming from a shop in Cairo. Chromolithograph

L'ART POUR TOUS, NO. 190, 15 NOVEMBER 1867, P. 758, ITEM NO. 1731 


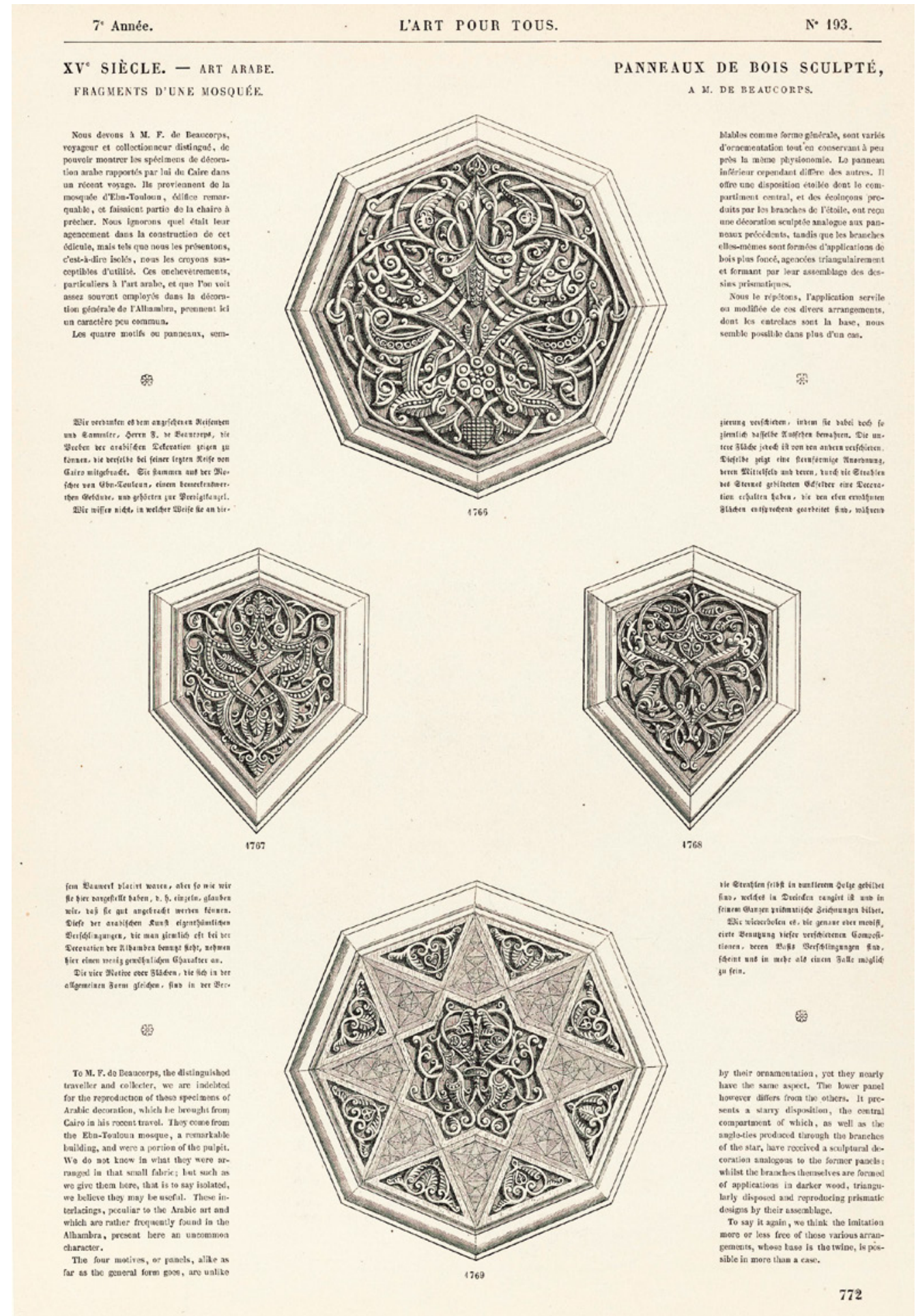

FIGURE 16 Panneaux de bois sculpté, fragment d'une mosquée, à M. de Beaucorps. Panels from the Lajin pulpit in the Mosque of Ibn Tulun in Cairo. Engraving

L'ART POUR TOUS, 1ST DECEMBER 1867, NO. 193, P. 772 


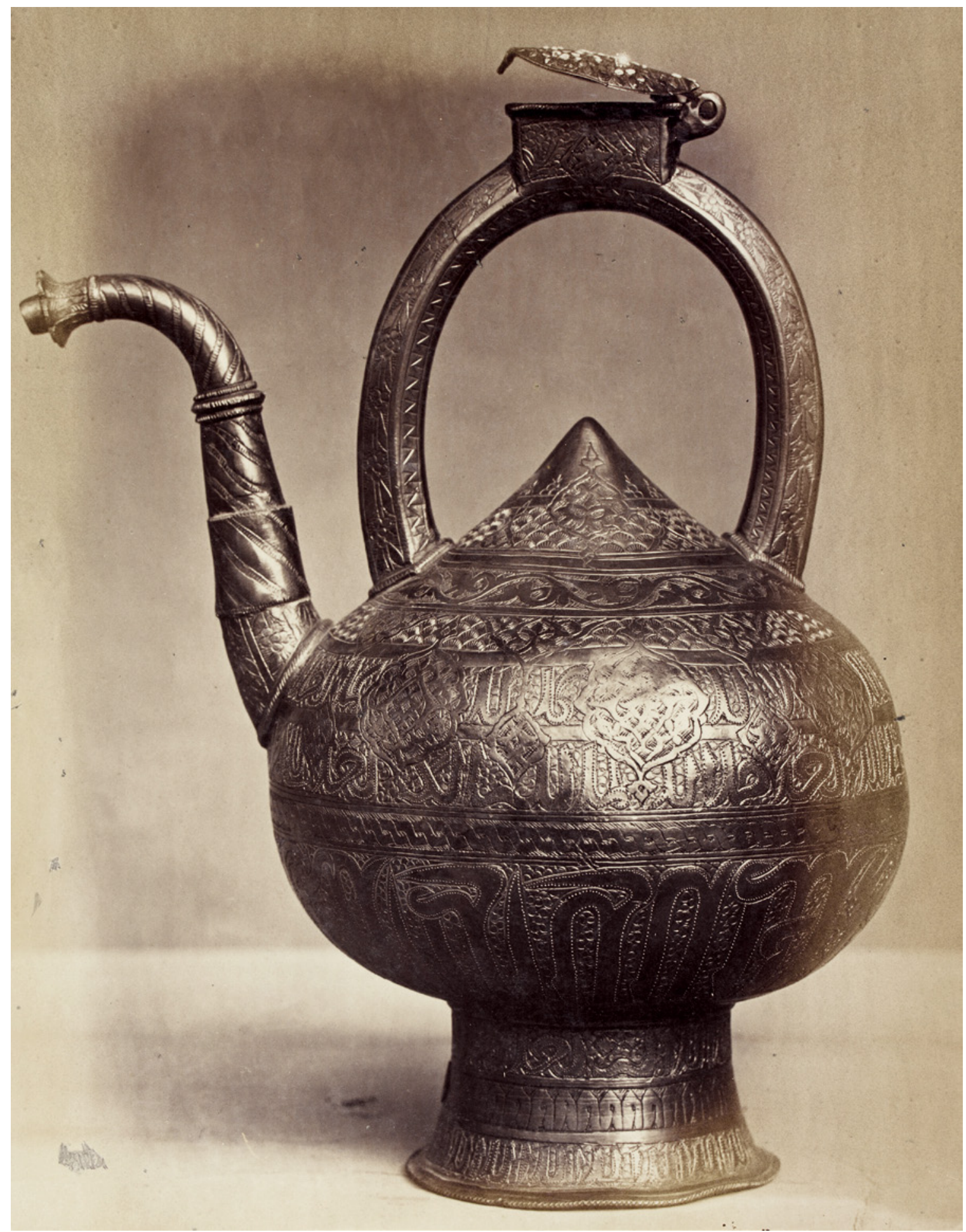

FIGURE 17 Franck, Théière orientale en cuivre gravé, collection M. de Beaucorps. Safavid ewer from Gustave de Beaucorps' collection, $32 \mathrm{~cm}$ height (current location unknown). Mounted albumen print. $23.9 \times 18 \mathrm{~cm}$. Franck, L'Art ancien: photographies des collections célèbres, 1868: $\mathrm{Pl} .200$ PARIS, BIBLIOTHÈQUE DE L'INHA, FOL EST 752 (2), F. 45 
The provenance given for at least three pieces from the Beaucorps collection is Cairo. His "Persian" helmets may have come from Istanbul, although through a channel other than arsenal clearance. Stylistically datable from late seventeenth to early nineteenth century, their period does not match an epoch of obvious Ottoman victory over Persia. No distinguishable tamga can be identified on the photographs; and similar specimens do not appear in photographs of the arsenal. However, Istanbul was still a place where arms could be procured. In his account of a visit to the city in $185^{2}$, the writer Théophile Gautier devotes several pages to the antiques shop favoured by foreigners in the Ottoman capital. Its owner was an Armenian who spoke French and had adopted the name of Ludovic. Numerous historic weapons and pieces of armour could be found on his shelves, including helmets, shirts of mail and shields. ${ }^{64}$ However, fakes and forgeries were soon to flood the market: in 1875 , an expert saw many pieces being openly crafted in workshops located by the grand bazaar. ${ }^{65}$ Whatever the provenance of Beaucorps' helmets, his collection is a useful index of European demand and Middle Eastern availability, in Cairo and Istanbul, of a given range of Islamic artworks, from 1858 to 1861 . Exposition universelle of 1867

A large group of Middle Eastern objects arrived in Paris two years after the UCAD show, but they came thanks to a completely different circuit. The occasion this time was the Universal Exposition of 1867 and, within it, the displays organised under the umbrella of Khedivial Egypt. For the first time, countries were represented by full-scale and free-standing architecture, instead of indoor

\footnotetext{
64 Théophile Gautier, Constantinople (Paris: Michel Levy, 1853), 123-24.

65 Paul Eudel, Le Truquage: altérations, fraudes et contrefaçons dévoilées (Paris: Molière, 19o8), 348.
}

installations as in earlier World's fairs. Previous exhibitions had represented architecture only by way of models or drawings; national exhibits were displayed in show-cases or along multidimensional arrangements in allocated stalls. ${ }^{66}$ Khedive Ismail (r. 1863-79) had arranged for a lavish showing, in line with his strategy of asserting Egypt's autonomy from the Sublime Porte. Substantial commercial space was obtained in the galleries of the Palais du Champ-de-Mars alongside the Turkish stands and almost as large in area; the stands were given Ancient Egyptian décor to distinguish themselves from the adjoining booths. ${ }^{67}$ Egypt also had a 6,ooo-square metre concession allotted to it in the gardens. Four pavilions were erected on the triangular plot. (Fig. 18) The largest was a caravanserai (okel or okelle in French sources, after the Arabic wakala), a commercial building arranged around a courtyard, and in this instance modelled on existing buildings in Upper Egypt. (Fig. 19) The structure was meant to embody Modern Egypt and featured craftsmen performing their art. At the opposite end of the section stood a salammlik or reception pavilion, erected as a rest house for the ruler; its function was to symbolise Medieval Egypt. (Fig. 20) In between was a building in the shape of an Egyptian temple for the display of Ancient Egyptian antiquities. At its rear, stables housed a pair of camels and two donkeys brought from Cairo.

\subsection{Official Exhibits}

A running theme throughout the Egyptian pavilions and galleries was the coexistence of historic craft and modern design, at times literally embedded into one another. Egypt had chosen to illustrate the overall theme of the exhibition, which was the history of labour, through a presentation of past and present handicrafts. Selected

66 Alfred Normand, L'Architecture des nations étrangères: étude sur les principales constructions du parc à l'Exposition universelle de Paris (1867) (Paris: A. Morel, 1870), 1.

67 H. Marini, "Les installations égyptiennes," in L'Exposition universelle de 1867 illustrée, 53-6o (54). 


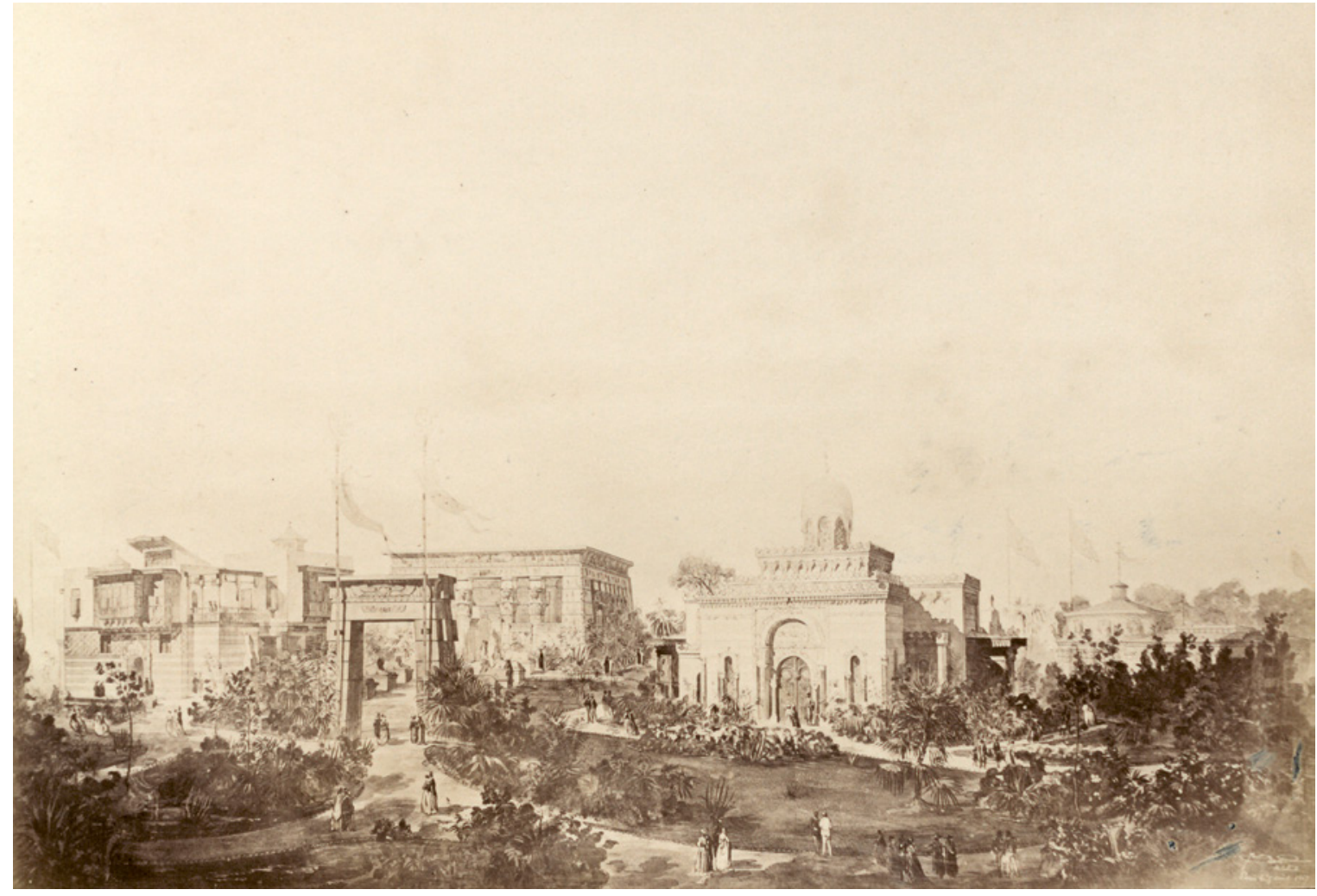

FIGURE 18 Henri Laurent, Exposition vice-royale égyptienne [A panorama of the Egyptian section at the Universal Exposition of 1867]. Mounted albumen print. $15 \times 22 \mathrm{~cm}$. Photographic reproduction of a watercolour by Jacques Drevet, dated 5 August 1867. Monuments de l'Exposition vice-royale égyptienne, 1868: $\mathrm{f}$. 1

BIBLIOTHÈQUE DE L'INHA, RÉSERVE DE LA BIBLIOTHÈQUE CENTRALE DES MUSÉES NATIONAUX, GR FOL 6

specimens of Islamic glasswork, metalwork, woodwork and calligraphy were displayed across the Egyptian exhibits. An enormous bronze lamp was hung at the centre of the covered courtyard of the okel. The provenance given at the time was one of the Qaytbay mosques (late fifteenth century). ${ }^{68}$ Thanks to its inscriptions, the chandelier was subsequently identified as a piece made in $730 \mathrm{H}$ (1330 AD) for the emir Qusun; it was suspended in the Mosque of Sultan Hasan before being transferred to the Museum of Islamic Art in Cairo. ${ }^{69}$ (Fig. 21)

68 Normand, L'Architecture, pl. 11.

69 Gaston Wiet, Catalogue général du musée arabe du Caire, objets en cuivre (Cairo: Institut français d'archéologie orientale, 1932), 40-1 (inv. 509), pl. viI.
Most of the mashrabiyas (screened windows made of lattice work) came from the palace of one Husayn Bey in Cairo; ${ }^{70}$ one was taken from the late eighteenth-century Cairene palace of Gamaliyya where Khedive Ismail was born (the palace was later known as al-Musafirkhana, literally "the travellers' inn," because the ruler had foreign hosts housed there on several occasions). Six glass lamps belonging to the Mamluk Mosques of Sultan Hasan and Barquq were suspended to the dome of the salammlik. In the central hall, opposite the entrance door, a precious fourteenth-century Qur'an was on display in a modern console featuring a panel made of old marquetry of wood and

70 Charles Edmond, L'Égypte à l'Exposition universelle de 1867 (Paris: Dentu, 1867), 220. 




FIGURE 19 Henri Laurent, Okelle, façade latérale. [Lateral elevation of the caravanserai]. Mounted albumen print. $15 \times 22 \mathrm{~cm}$. Monuments de l'Exposition vice-royale égyptienne, 1868: f. 10 PARIS, BIBLIOTHÈQUE DE L'INHA, RÉSERVE DE LA BIBLIOTHÈQUE CENTRALE DES MUSÉES NATIONAUX, GR FOL 6

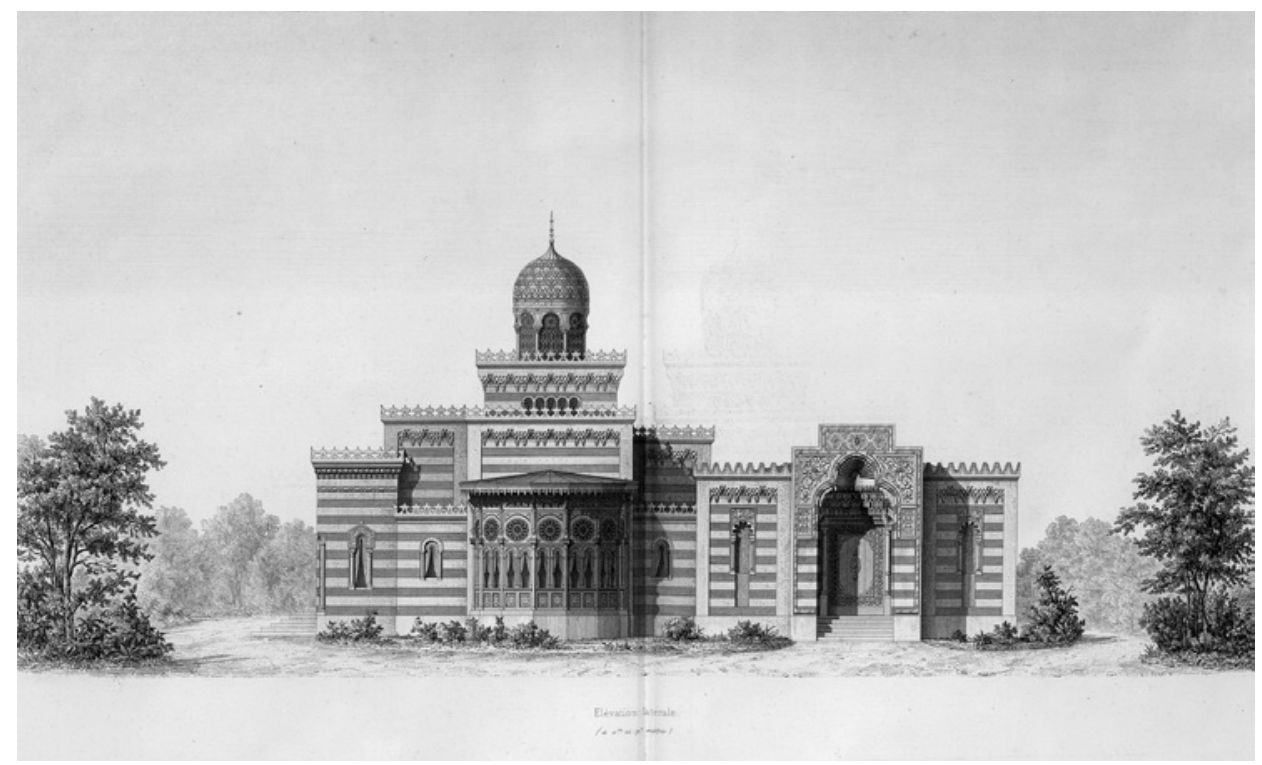

FIGURE 20 Jacques Drevet, Sélamlick, Elévation latérale. [Lateral elevation of the Khedivial reception pavilion designed by architect Jacques Drevet]. Engraving LA REVUE GÉNÉRALE DE L'ARCHITECTURE ET DES TRAVAUX PUBLICS XXVIII, 1870: PL. 47-48 


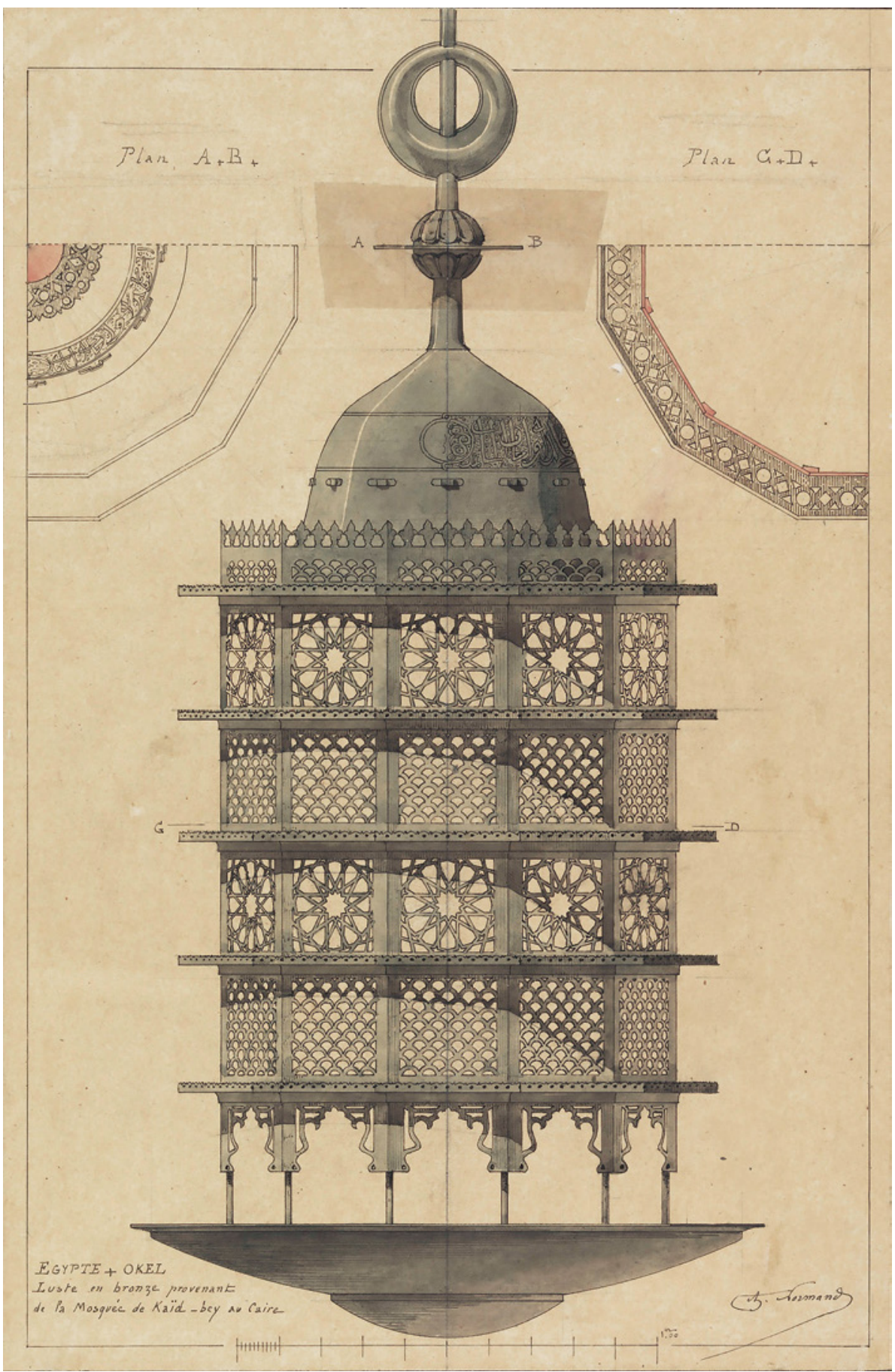

FIGURE 21 Alfred Normand, Lustre en bronze provenant de la mosquée de Kaid-bey au Caire, 1866. A Mamluk bronze hanging lamp exhibited at the Egyptian section of the Universal Exposition of 1867 in Paris as a piece from a Qaytbay mosque. It came in fact from the Mosque of Sultan Hasan. Pen and black ink, grey wash and watercolour on tracing paper mounted to heavy wove paper. $47.8 \times 30.8 \mathrm{~cm}$ NEW YORK, COOPER HEWITT MUSEUM, DRAWINGS, PRINTS AND GRAPHIC DESIGN DEPARTMENT, 1992-147-3 




FIGURE 22 Henri Laurent, Salamlik, Intérieur. Interior view of the salāmlik showing the Qur'an cabinet behind the bust of Khedive Ismail. Mounted albumen print. $15 \times 22 \mathrm{~cm}$. Monuments de l'Exposition vice-royale égyptienne, 1868: f. 4 PARIS, BIBLIOTHÈQUE DE L'INHA, RÉSERVE DE LA BIBLIOTHÈQUE CENTRALE DES MUSÉES NATIONAUX, GR FOL 6

ivory (Fig. 22, 23). ${ }^{71}$ Similarly several doors of the salāmlik had historic woodwork repurposed as panels (Fig. 24).

Other doors were described as "restorations",72 a term used then for creative historicist craftsmanship. Revival design could involve literal imitation; the entrance doors to the exhibition hall adjoining the salāmlik had wooden replicas of the bronze plating decorating the entrance of the eighteenth-century public fountain and school of 'Abd al-Rahman Katkhuda in Cairo. ${ }^{73}$ (Fig. 25 and

\footnotetext{
71 Edmond, L'Égypte, 196.

72 Edmond, L'Égypte, 196.

73 The bronze plating was itself a restoration made around 1800 after the original door had been
}

26) Other pieces in Mamluk style were more freely designed. This is the case with a large cupboard dated 1866 and signed by the Italian cabinetmaker Giuseppe Parvis (1832-19o9). Made for one of the private rooms of the salamlik, the gigantic piece of furniture, modelled after a scaled-down Mamluk portal, bore a rhyming eulogy to the Khedive, praising his guidance for the revival of the past splendour of Egyptian arts and crafts. The text was authored by his preferred panegyrist, Sheikh Mustafa Salama al-Najjari. ${ }^{74}$ The cupboard

accidentally destroyed; Normand, L'Architecture, pl. 18; Prisse d'Avennes, L'Art arabe, pl. CV and III: 273.

74 Illustrierter Katalog der Pariser Industrie-Ausstellung von 1867, foreword by Wilhelm Hamm (Leipzig: 


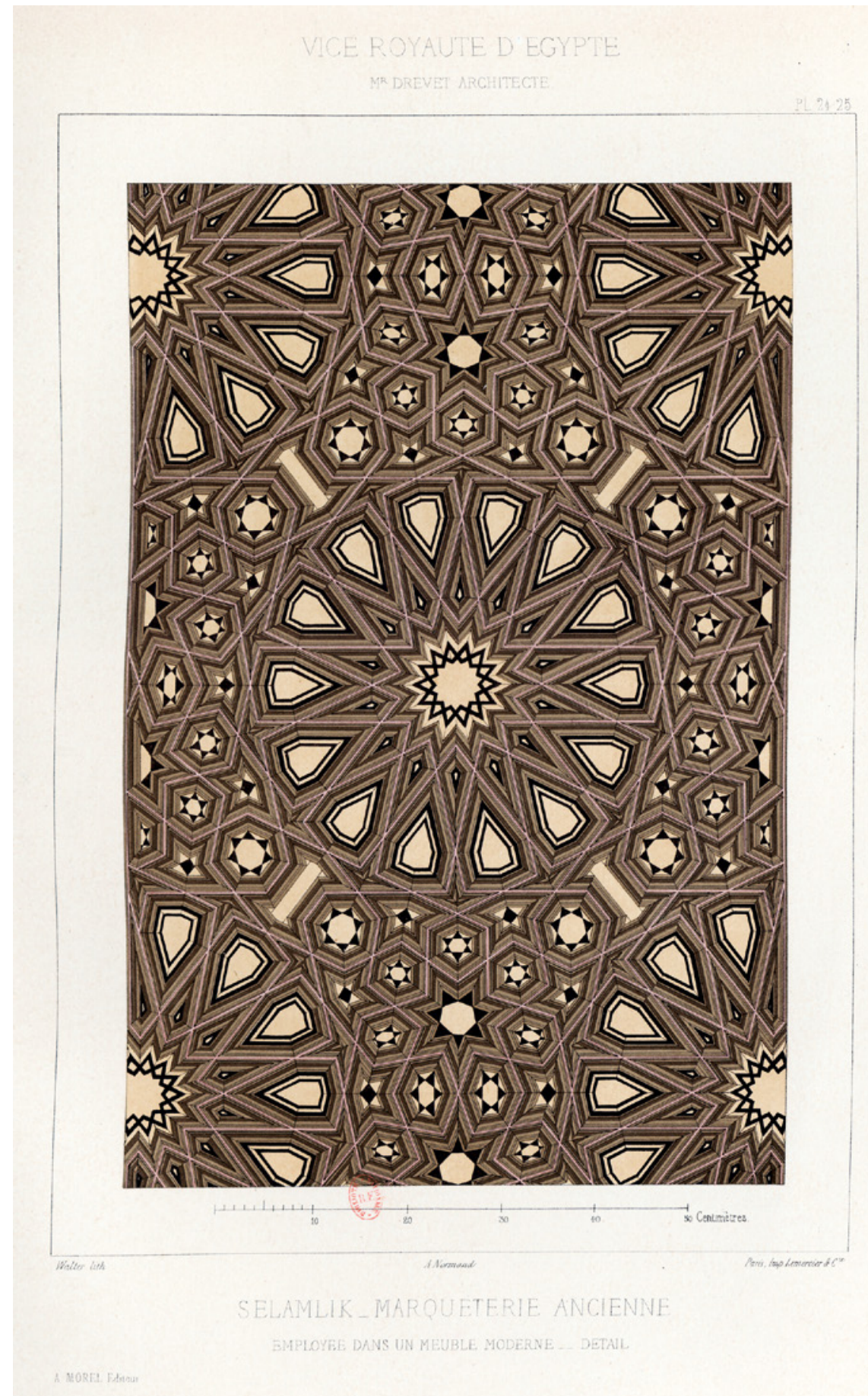

FIGURE 23 Alfred Normand, Marqueterie ancienne employée dans un meuble moderne. Old marquetry used in a piece of modern furnishing. Chromolithograph

ALFRED NORMAND, L'ARCHITECTURE DES NATIONS ÉTRANGÈRES, 1867: PL. 24-25 


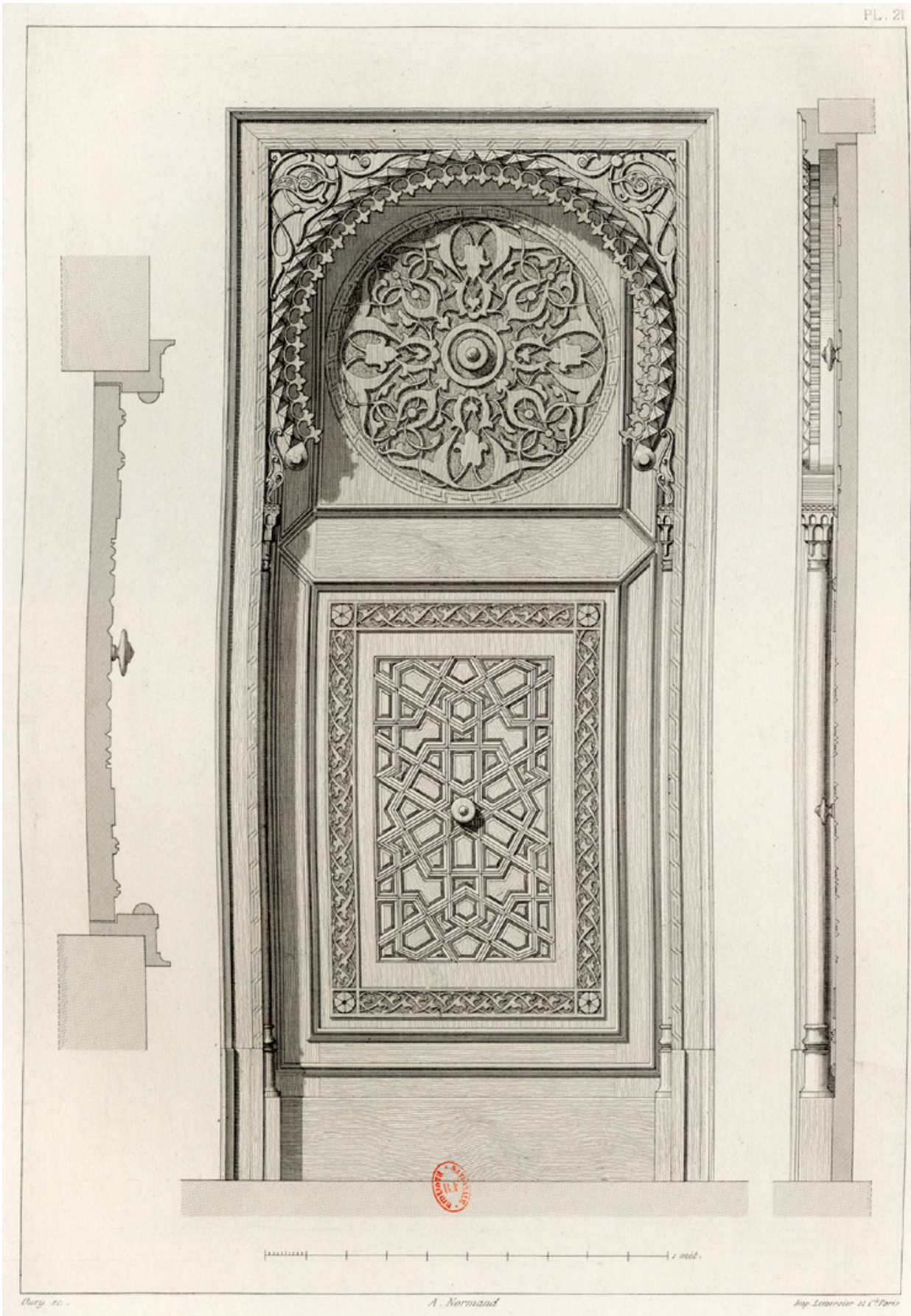

FIGURE 24 Alfred Normand, Selamlik, porte de la salle centrale. Modern door incorporating historic panels in the central hall of the salämlik. Engraving ALFRED NORMAND, L'ARCHITECTURE DES NATIONS ÉTRANGÈRES, 1867: PL. 21 


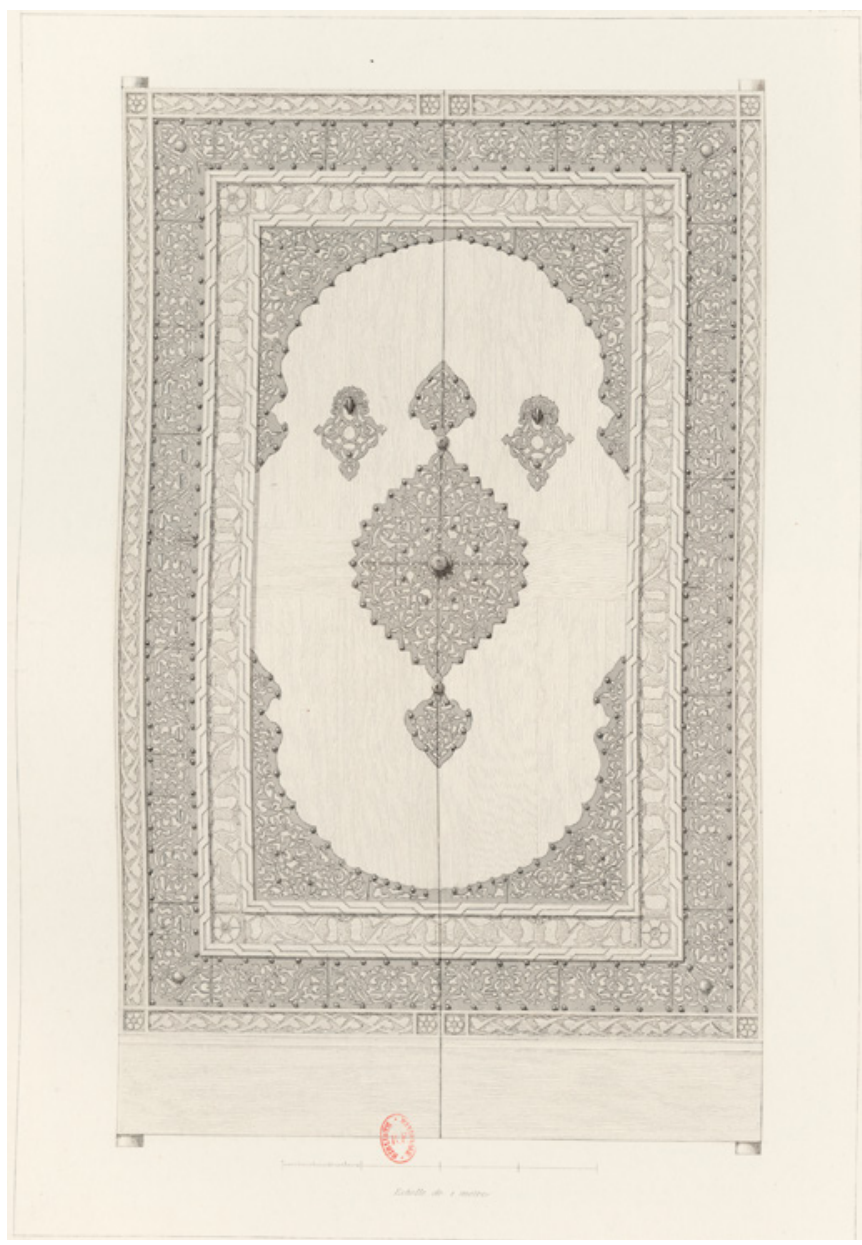

FIGURE 25

Alfred Normand, Selamlik, porte de la fontaine d'Abd el Rahman au Caire. Entrance door to the salämlik with a replica of the bronze plating from the entrance to the fountain of 'Abd al-Rahman Katkhuda in Cairo. Engraving ALFRED NORMAND, L'ARCHITECTURE DES NATIONS ÉTRANGÈRES, 1867: PL. 18

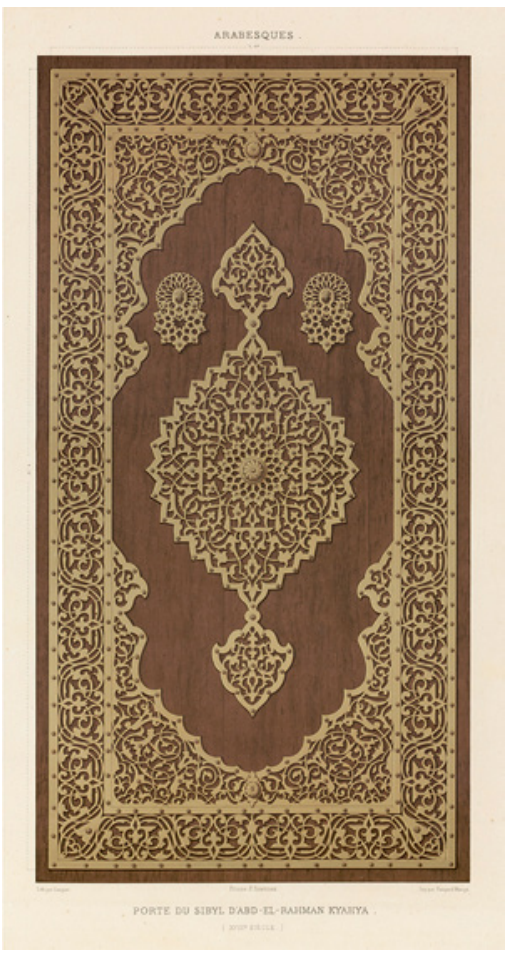

FIGURE 26

Émile Prisse d'Avennes, Porte du sibyl d'Abd-El-Rahman Kyahya (XVIII siècle). Door to the Fountain of 'Abd al-Rahman Katkhuda in Cairo. Chromolitograph ÉMILE PRISSE D'AVENNES, L'ART $A R A B E$... 1869-77, III: PL. CV 
now stands in a corridor of Cairo's Marriott Hotel, formerly the Khedivial Palace of Gazira. (Fig. 27)

The exhibition hall adjacent to the salämlik had a large scale relief map of Egypt covering forty-five square metres. Other maps hang on the walls. One side of the hall was lined with glazed cupboards presenting 400 books in Turkish or Arabic from the Bulaq Press, including translations from French authors. Many of these belonged to Gustave Le Gray (1820-84), the famous photographer who had been living in Egypt since 1862; some of the Arabic manuscripts on show were also his. Beside these were photographic albums by the Frenchman Désiré Ernié (1830-?), depicting ancient monuments, as well as people and objects. ${ }^{75}$

\subsection{A Private Initiative: The Meymar Display}

The Egyptian galleries located in the Palais du Champ-de-Mars accommodated the remaining items presented by Egypt. They featured a collection of national costumes, arranged on mannequins executed by the French sculptor Charles Cordier (1827-1905). More importantly, they included a "collection of Arab antiquities,"76 most probably installed in the Egyptian part of the circular section reserved for the museum of the history of labour that cut across all national stalls. This collection was curated by an individual generally identified in European sources as Doctor Meymar ${ }^{77}$ or Meymarie. ${ }^{78}$ He was not a doctor and should

Brockhaus, 1868), 202; Edmond, L'Égypte, 255 , 335-36. On Ismail's panegyrist, see Adam Mestyan, Primordial History, Print Capitalism, and Egyptology in Nineteenth-Century Cairo, Muștafā Salāma al-Nağğārìs The Garden of Ismail's Praise (Cairo: Publications de l'IFAO, 2021).

Edmond, L'Égypte, 231, 332, 370. His name is frequently misspelled as Ermé.

76 Hôte, "L'Égypte à l'Exposition universelle de 1867," La Science pittoresque, 13 March 1867, 155-57.

77 Edmond, L'Égypte, 199.

78 Adalbert de Beaumont, "Les Arts décoratifs en Orient et en France. Une visite à l'Orient à l'Exposition Universelle," Revue des deux mondes LXXII (1st November 1867): 138-6o (143). not be confused with Dr. Alexandre de Meymar, a physician practicing in Paris in the 188 os. The title of Doctor did not necessary denote a member of the medical profession; it was given to people with renowned expertise in any domain of knowledge. At the time, one Dr. Alexandre Foresi, for instance, bore the title as a specialist in detecting forgeries. ${ }^{79}$ The name Meymar transcribes in fact an approximate oral pronunciation of the word mi'mār, meaning architect or rather buildingsurveyor in Arabic; the title was usually transliterated as Meymar in nineteenth-century European sources. ${ }^{80}$ This clue, supplemented by biographical data, ${ }^{81}$ led "Doctor Meymar" to be identified as Husayn Fahmi al-mi'mār (c. 1827-91), alternatively known in the literature as "Cutchuk Hussein Pacha” (Küchük meaning little, i.e. young here, in Turkish), ${ }^{82}$ Husseïn Pacha Maïmar ${ }^{83}$ or Hussein Pacha Meimar. ${ }^{84}$ The man belonged to a family of "Albanese" origin (possibly from Macedonia) close to the ruling family. Husayn, following his father 'Abd al-Karim, had benefited from the program of educational missions that sent young literate men to European capitals for knowledge transfer in science and technology. After studying engineering in France in 1844-49, Husayn had held successive

79 Dr. Alexandre Foresi, Tour de Babel ou Objets d'art faux pris pour vrais et vice-versa (Paris: Pedone-Lauriel, 1868).

80 Ambroise Calfa, Guide de la conversation français-turc (Paris: Garnier frères, 1859, 2d edition), 84.

81 Entries on Husayn Fahmi exist in 'Umar Tusun, Al-ba'that al-ilmiyya fi' 'ahd Muhammad 'Alì wa 'Abbas wa Said [The Educational Missions during the Reign of Muhammad Ali, Abbas and Said] (Cairo: n.p., 1934), 292-95; James Heyworth-Dunne, An Introduction to the History of Education in Modern Egypt (London: Cass, 1968), 257; 'Abd al-Rahman al-Rafi'ī, 'Asr Muhammad 'Ali [The Era of Mehmed Ali], fourth ed. (Cairo, 1982), 419, 484.

82 Yacoub Artin, "Description de six lampes de mosquée en verre émaillé," Bulletin de l'Institut égyptien (1886): 120-54 (126).

83 Gabriel Charmes, "L'Art arabe au Caire," Journal des débats, 2 August 1881.

84 Almanach de Gotha (1888), 1044. 


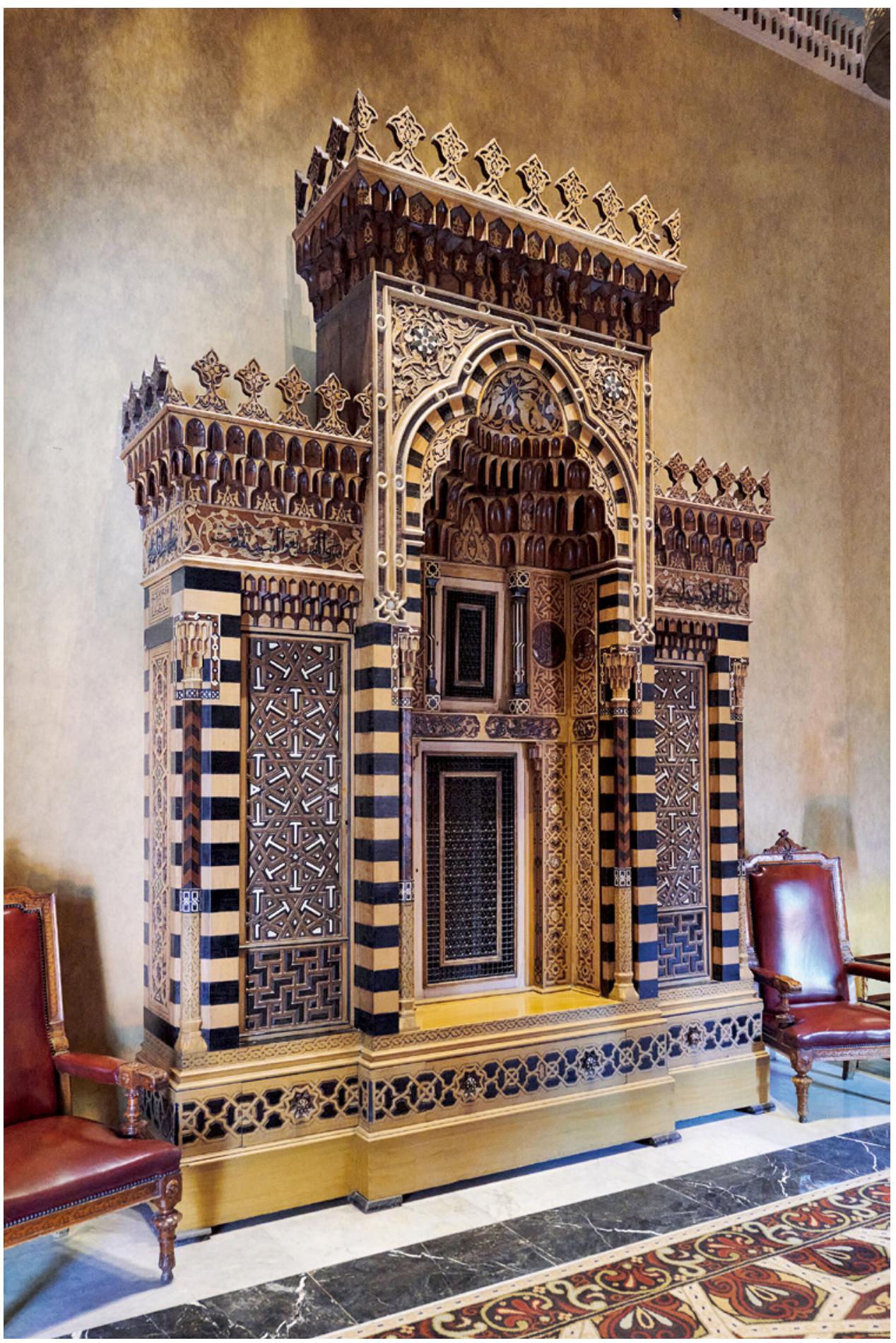

FIGURE 27 Cupboard made by Giuseppe Parvis for the Khedivial salāmlik at the Paris Universal Exposition of 1867, signed and dated 1866 (currently located in the Marriott Hotel in Cairo) PHOTOGRAPH BY MATJAZ KACICNIK, 2020 
positions in the Egyptian administration. In 1864, he was listed as chief architect for urban embellishment work in Cairo, and was to rise to the head of that administration in the following years. ${ }^{85} \mathrm{He}$ ended his career as wakil [undersecretary] of the Administration of $A w q \bar{a} f$ [religious endowments] from 1881. He was known to fellow architects in Egypt for his love of books and penchant for drawing, as well as kindness to his staff. His little appetite for public life was also widely known, ${ }^{86}$ a trait that conforms with the discrete nature of many a collector.

Although no catalogue exists of the pieces that Meymar exhibited in 1867 , passing mentions do appear in descriptions of the Universal Exposition. But it is the subsequent acquisition of a good share of his collection by the South Kensington Museum that allows a reconstruction of its composition. ${ }^{87}$ As early as the end of May 1867, within a few weeks after the opening of the Universal Exhibition on 1st April 1867, Husayn Fahmi had approached the nascent London museum of art and industry with a view to selling or loaning his collection. ${ }^{88}$ Owen Jones, the illustrious author of the Grammar of Ornament, was dispatched to Paris in June 1867 , in order to inspect it, together with the numismatist Reginald Stuart Poole and the art referee John Charles Robinson. The sixteen-folio memorandum

85 Amin Sami, Taqwim al-nil [The Nile Almanach] (Cairo: Mațba' Dār al-kutub al-mișriyya, 1915-36) III: Part 2, 584. He was replaced as head of Cairo's urban embellishment bureau in 1873 by French civil engineer Pierre Grand, according to a document listing personnel and monthly salaries in the Department of Parks and gardens and other administrations, ca. 1875; Cairo, Dār al-Wațāiq al-Qawmiyya, Muhāfaza Misr, Mahāfị̣ 1872, 2002-36o7.

86 Istvan Ormos, Max Herz Pasha (1856-1919), His Life and Career (Cairo: Publications de l'IfAO, 2009), II: 435.

87 Moya Carey and I are working at the reconstruction of the Meymar collection as part of a research on Early Islamic art collecting at the V\&A.

88 Kew, The National Archives, Minute books of the board meetings of the Department of Practical Art and its successor, the Science and Art Department (18521876), ED28/22, Fol 157-159, \# 13975, 31 May 1867. drafted by Stuart Poole does not seem to have survived, but extracts published thereafter do still exist. ${ }^{89}$ The numismatist recommended the purchase on the basis of provenance, chronology and quality, as most pieces were identifiably Egyptian ("Arab art is acknowledged to be best represented by its Egyptian branch, the purest in style"), and were "works of the first importance," with many bearing dates. ${ }^{90}$ The substantial amount asked for the whole collection $(£ 6,0 \circ)$ provoked much discussion when the proposed purchase of the "Meymar collection of Arabian ornament" was examined in June 1867 by a committee specially appointed by the House of Commons. ${ }^{91}$ The price was considered extravagant and unreasonable, but the purchase still deemed desirable as it represented a unique opportunity. As Henry Cole, the director of the South Kensington Museum, brought to the fore: "It is rarely that you can buy the old art of Cairo."92 It was agreed to select the most important pieces for a sum not exceeding $£ 2$,ooo. On 30 August 1867 , Jones reported that he had been able to secure the most significant part of the collection for $£ 2,100 .{ }^{93}$ The selection proceeded to store on 14 October 1867, two weeks before the end of the Parisian exhibition on 3 November 1867 . For some reason yet to be ascertained (perhaps loan before acquisition), the

89 "Report by Mr R. Stuart Poole on the Meymar collection," Fifteenth Report of the Science and Art Department of the Committee of Council on Education (London: George Eyre and William Spottiswoode, 1868), 231-34. "Report by Mr R. Stuart Poole," 231-32.

The discussion and recommendations made by the referees are recorded in Report from the Select committee on Paris exhibition; Together with the Proceedings of the Committee, Minutes of Evidence, and Appendix (House of Commons, [1868]).

Report from the Select Committee, 35 .

Kew, The National Archives, "Minute books of the board meetings of the Department of Practical Art and its Successor, the Science and Art Department (18521876)," ED28/22, f. 211 - letter \# 20905, Report from Owen Jones, 20 August 1867. 
accessioned objects (about 200 pieces) were only registered in the museum in $1869 .{ }^{94}$

The acquisition included one of the three enamelled glass mosque lamps exhibited in Paris ${ }^{95}$ and three tiles. It also comprised Qur'an folios and copies of religious texts made during the reign of Qaytbay with elaborate title pages, as well as large bindings. The Orientalist Émile Prisse d'Avennes drew parts of the leaves on show, and thought that they had belonged to the waqf of Sultan al-Gawri and had been copied at the time of the building of his mausoleum, in the early sixteenth century. (Fig. 28) Prisse also recalled that when repairs were made on the dome of the sanctuary in 1858 , one of its most beautiful Qur'ans was carried away and sold to a Greek individual who brought it to Paris. ${ }^{96}$ Qur'an's folios were known to circulate in Paris: a friend of Prisse d'Avennes, the artist Charles Cournault possessed dozens of folios from a Qur'an in the name of Sultan Barquq that he had acquired in Paris on Quai Voltaire in 1850.97 Is it where Meymar may have acquired his leaves too? It is known that the Egyptian art lover did purchase collectibles on the Parisian market, for example at the sale in 1868 of objects brought back from Persia by the art dealer Ferdinand Méchin, ${ }^{98}$

94 Inventory numbers: $1049-1869$ to $1087-1869$; "Dr Meymar's collection," in Science and Art Department, List of Objects Obtained during the Paris Exhibition of 1867 by Gift, Loan or Purchase, and now Exhibited in the South Kensington Museum (London: H.M. Stationery office, 1868), 52-4; List of the Objects in the Art Division, South Kensington Museum, Acquired during the Year 1869, Arranged According to the Dates of Acquisition (London: H.M. Stationery office, 1870), 78-81. The lamp bears the name of Sayf al-Din Aqbugha, and is dated c. 1340 (V\&A, 1056-1869).

96 Prisse d'Avennes, L'Art arabe, 286, pl. ClXxxiII.

97 Emmanuel Hecre, Les Orients de Charles Cournault (Mazeville: Serge Domini éditeur, 2004), 193.

98 Méchin had been dispatched to Iran in 1867 by the Sèvres Imperial Manufactory of Porcelaine to purchase specimens of Persian wares for its museum; Carey, Persian Art, 70-6. as evidenced by the minutes of the sale recording metalwork acquisitions by Meymar. ${ }^{99}$

Two Meymar metal objects, now in the Victoria and Albert Museum, do have Persian - and hunting - connections. One is a circular mirror, with a mounted falconer circled by Arabic script, and "magical" inscriptions on the reverse. This type of object, of which many examples survive, is generally attributed to Iran, probably Khorasan, and dated twelfth/thirteenth century. ${ }^{100} \mathrm{~A}$ similar one from the Schefer collection, now at the Bibliothèque nationale de France, has been dated to the twelfth century. ${ }^{101}$ The other Persian artwork is a drum used by falconers to recall their birds. One wonders if Husayn Fahmi was intending to document falconry or Iranian metalwork? In wood, the Egyptian collector owned, as Beaucorps, panels from the Mamluk minbar offered by Sultan Lajin to the Mosque of Ibn Tulun on the occasion of a major renovation of the site in 1296. Meymar had eight loose partially damaged panels, ${ }^{102}$ (Fig. 29) and several dozens more that were arranged in London into a square wooden frame by British artist James Wild (1814-92). ${ }^{103}$ According to one source, the Egyptian official had helped to salvage threatened woodwork in that mosque:

Le docteur Meymarie [sic] a eu l'heureuse idée de ramasser les boiseries, portes, volets, morceaux de plafonds et grilles sculptées, provenant de la mosquée El-Teyloun [Ibn Tulun]. [...] En réparant certaines parties du

99 Archives de Paris, Minutes de ventes des commissairespriseurs, Étude de maître Pillet, Ventes 1868, D. 48 E 3 59 (file 1647).

100 London, v\&A, 1859-1869; Ladan Akbarnia et al., The Islamic World: A History in Objects (London: Thames and Hudson, 2018), 100-01.

101 Catalogue Schefer, lot no. 159, currently labelled as "miroir persan" (Paris, Bnf, Médailles et antiques, $55 \cdot 536)$.

102 London, V\&A, 1085-1869.

103 London, V\&A, 1051-1869; Stanley Lane-Poole, The Art of the Saracens in Egypt (London: Chapman and Hall, 1886), $115^{-16 .}$ 


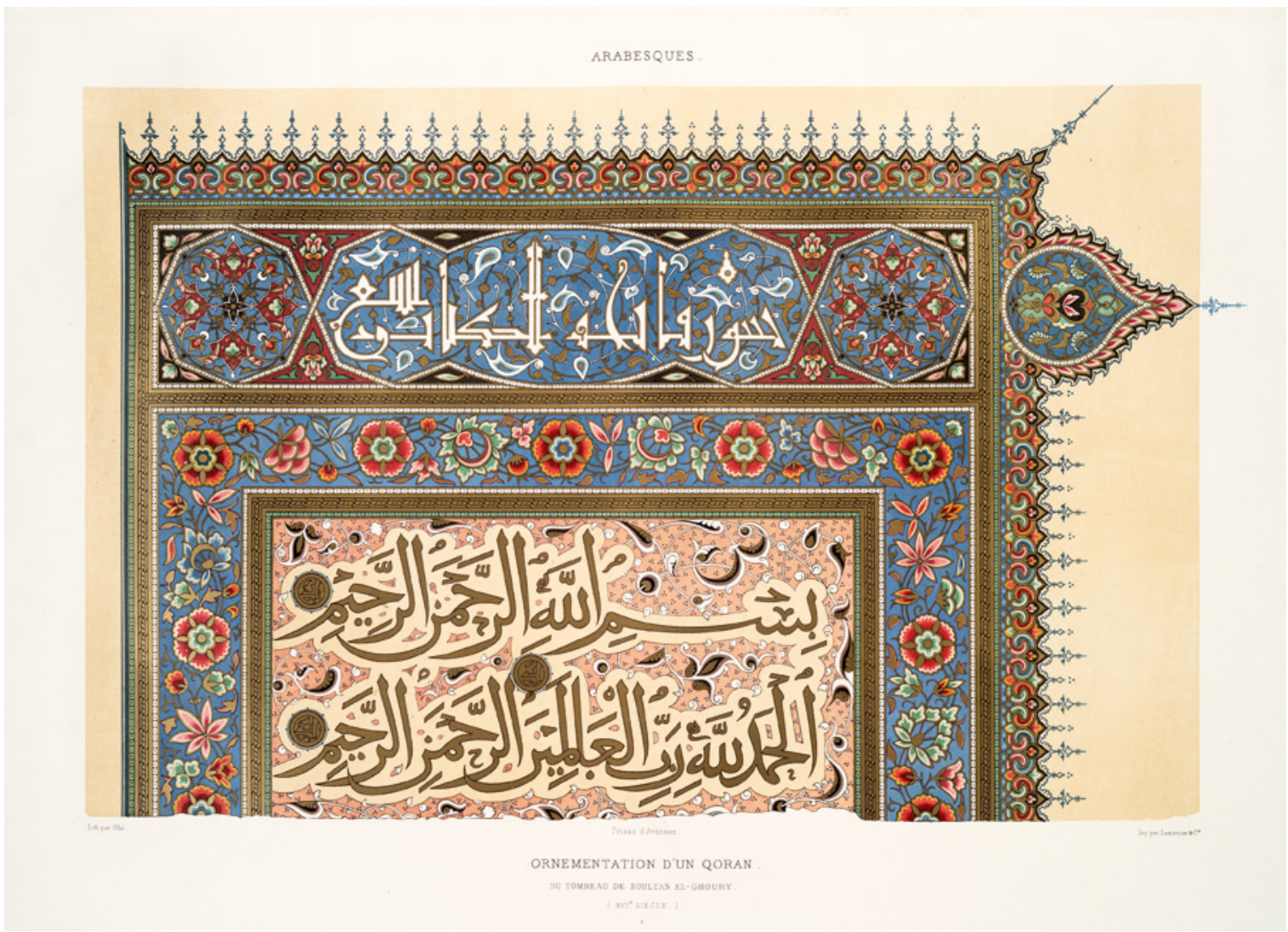

FIgURE 28 Émile Prisse d'Avennes, Ornementation d'un Qoran du tombeau du Soultan el-Ghoury. Part of a Qur'an leaf from the Mausoleum of Sultan al-Gawri. Chromolithograph PRISSE D'AVENNES, L'ART ARABE ... 1869-77, III: PL. CLXXXIII

mirab [sic for mihrab] ou sanctuaire, on avait abattu et jeté parmi les gravats une foule de détails ravissants, où des nielles de nacre, d'ivoire et d'ambre se mêlent au cèdre et à l'ébène. M. Meymarie a recueilli et sauvé ces débris. ${ }^{104}$

"Dr Meymarie [sic] had the happy idea of collecting the panels, doors, shutters, ceiling fragments and carved screens coming from the mosque of Ibn Tulun. [...] When repairs were made to certain parts of the prayer hall, a number of gorgeous pieces in varied species of wood were damaged and thrown away. M. Meymarie collected and saved these debris", my translation from de Beaumont, "Les Arts décoratifs en Orient et en France," 143.
The testimony validates what the director of the South Kensington Museum was told about the collection: occasions to procure such historical art were extremely rare. Cole had been informed that "The gentleman who has made this collection is one who watched the demolition of mosques and other things, and has managed to get these things." 105

When, during a visit to Cairo in 1844 , Wild had sketched the minbar of the mosque, it was intact. ${ }^{106}$ In 1846 , the sanctuary was converted into a refuge for the needy elderly. The pointed arches were

\footnotetext{
105 Report from the Select Committee, 35.

106 Élise Anglade, Musée du Louvre, Catalogue des boiseries de la section islamique (Paris: Rmn, 1988), 89.
} 


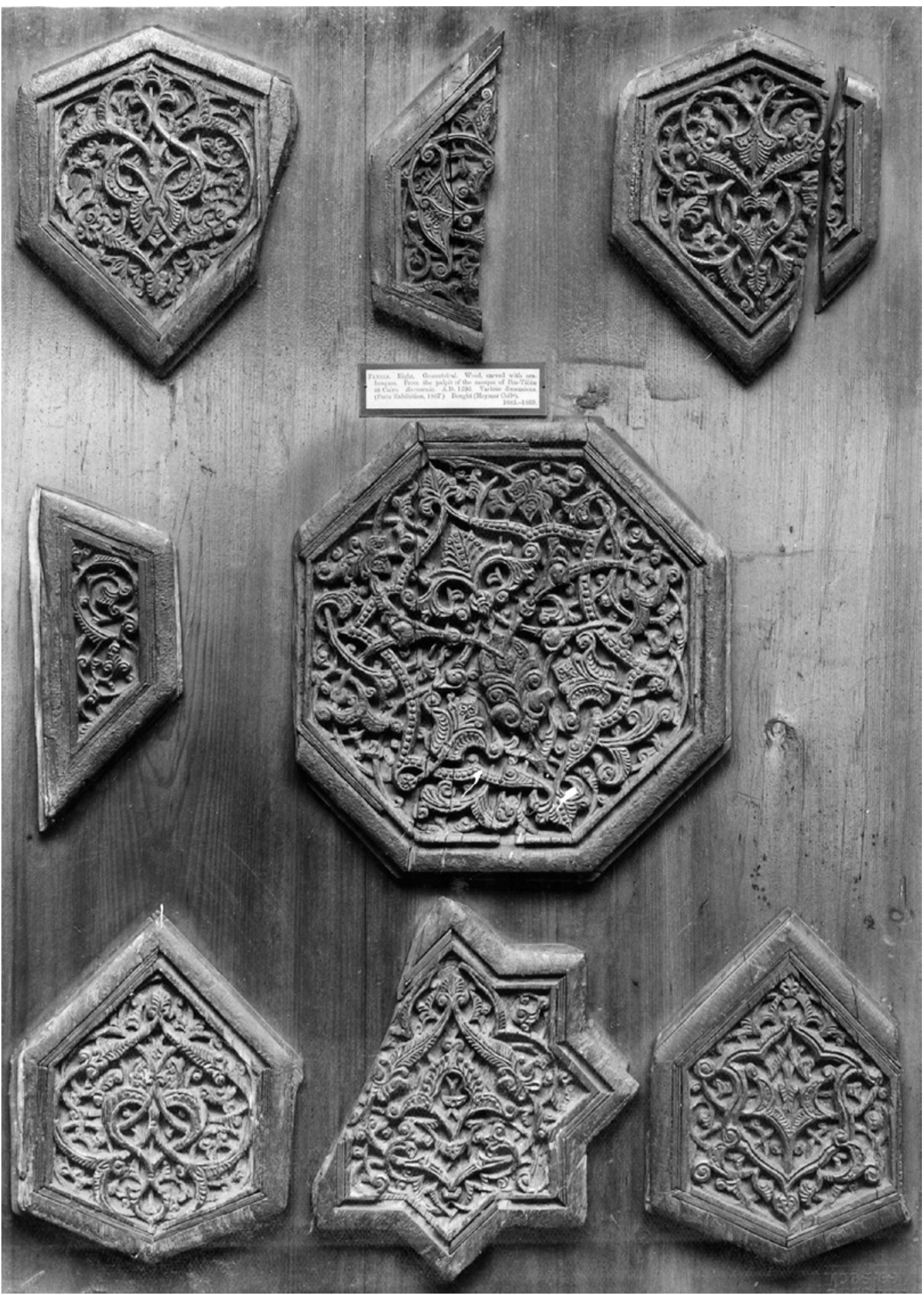

FIGURE 29 Eight panels from the Lajin minbar in the Meymar collection mounted on a board. Guardbook photograph

LONDON, VICTORIA AND ALbERT MUSEUM, PRINTS AND DRAWINGS DEPARTMENT, NEGATIVE NUMBER 63866; PHOTOGRAPH DEPICTS OBJECT 1085-1869 


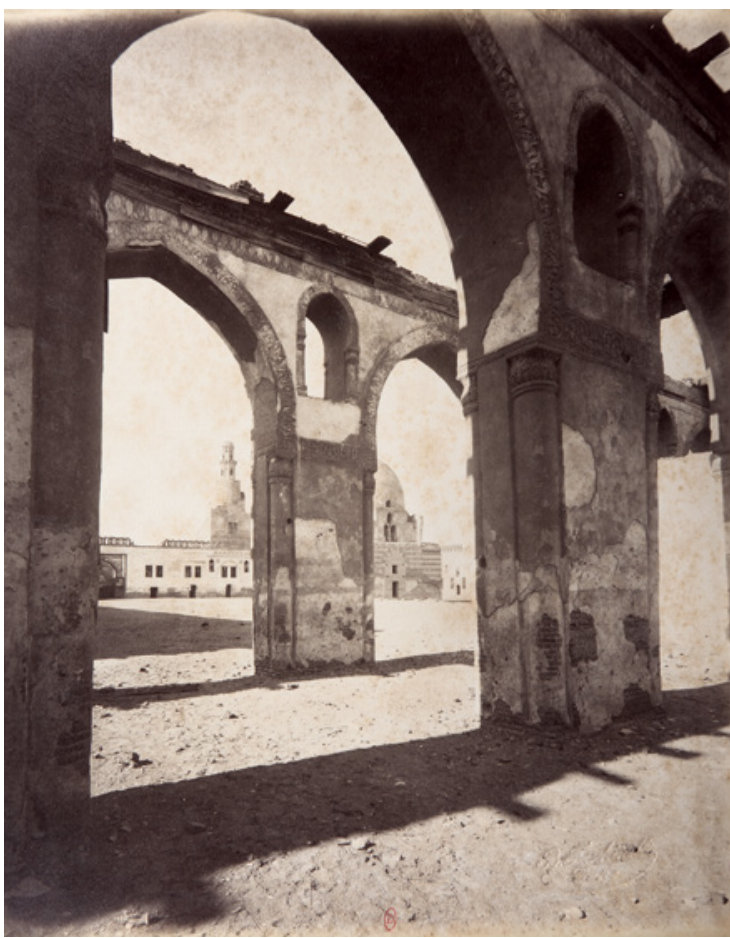

FIGURE 30 Beniamino Facchinelli, Interno del Tulun [An internal view of Ibn Tulun Mosque]. Mounted albumen print. $21 \times 27 \mathrm{~cm}$. Raccolta artistica di fotografie sull'architettura araba, ornati ecc. dal $X I I^{\circ}$ al XIII ${ }^{\circ}$ secolo fotografia italiana del Cav. B. Facchinelli, Cairo (Egitto) MDXXXLXXXVII [sic: $\mathrm{XXX}$ for CCC, i.e. 1887 ], f. $5^{\circ}$ PARIS, BIBLIOTHÈQUE DE L'INHA, FOL PHOT 65

walled up (Fig. 30) and the mosque ceased to function as a place for prayer. By 1856 , one hundred families were living in it. ${ }^{107} \mathrm{~A}$ photograph published in 1887 shows a minbar that had sadly lost, probably long since, all its carved panels (Fig. 31).

Lajin panels remained a must-have collectible. Most major world museums have a number in their collections. The Museum for Art and Industry in Vienna managed to buy a set of 35 panels forming a complete rosette at the Paris Exposition in $1867,{ }^{108}$ and pieces from that very pulpit continued to flow to Europe and the US. Four were donated to the

\footnotetext{
107 Tarek Swelim, Ibn Tulun, His Lost City and Great Mosque (Cairo: Auc Press, 2015), 206-07.

108 Chris Dercon et al., The Future of Tradition, 94.
}

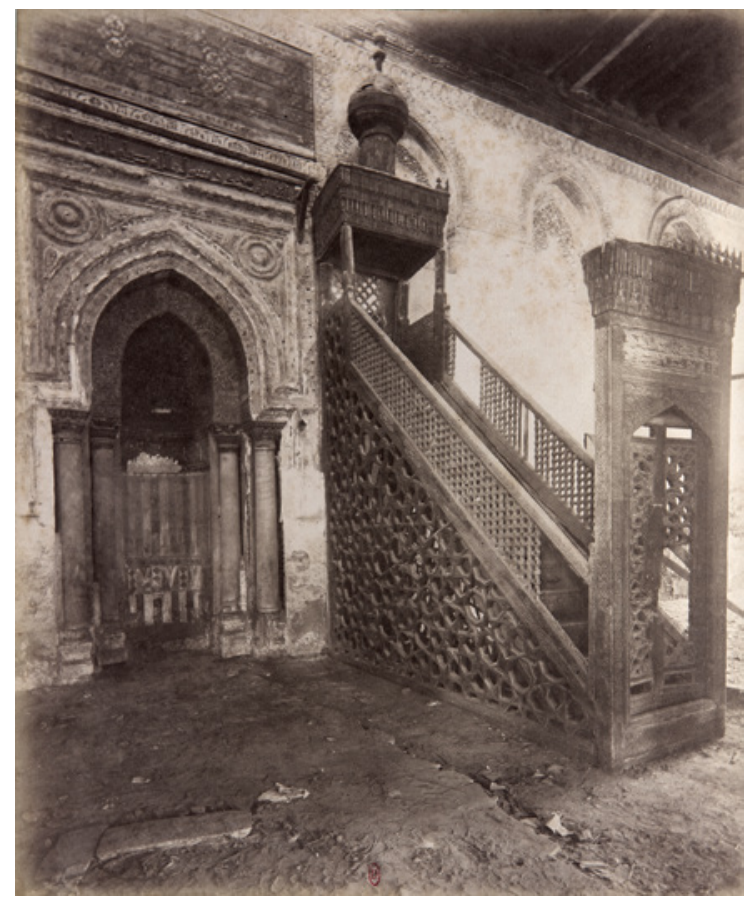

FIGURE 31 Beniamino Facchinelli, Interno del Tulun [A view on the minbar of the Ibn Tulun Mosque]. Mounted albumen print. $22 \times 26 \mathrm{~cm}$. Raccolta artistica di fotografie sull'architettura araba, ornati ecc. dalXII ${ }^{\circ}$ al XIII ${ }^{\circ}$ secolo fotografia italiana del Cav. B. Facchinelli, Cairo (Egitto) MDXXXLXXXVII [sic: XXX for CCC, i.e. 1887], f. 47 PARIS, BIBLIOTHÈQUE DE L'INHA, FOL PHOT 65

Musée du Louvre in 1905. The Met acquired fourteen pieces in 1907. A survey carried out in 2008 identified 179 specimens in Western collections. ${ }^{109}$ Panels still surface in auction houses: one was offered at a Sotheby's sale in $2011 .{ }^{110}$ From pulpits, Meymar also had carved polygons and inscribed woodwork coming from another mosque, the Mosque of al-Maridani, which had suffered greatly during an earthquake in 1856 . (Fig. 32)

109 Désirée N. Heiden, "Auf der Suche nach dem verlorenen Minbar," in Von Gibraltar bis zum Ganges: Studien zur Islamischen Kunstgeschichte in memoriam Christian Ewert, eds. Marion Frenge, Martina Müller-Wiener (Berlin: Е B-Verlag, 2010), 75-95.

110 Arts of the Islamic World, 5 October 2011, Sotheby's London, lot 243, estimated £18,ooo-25, ooo (unsold). 


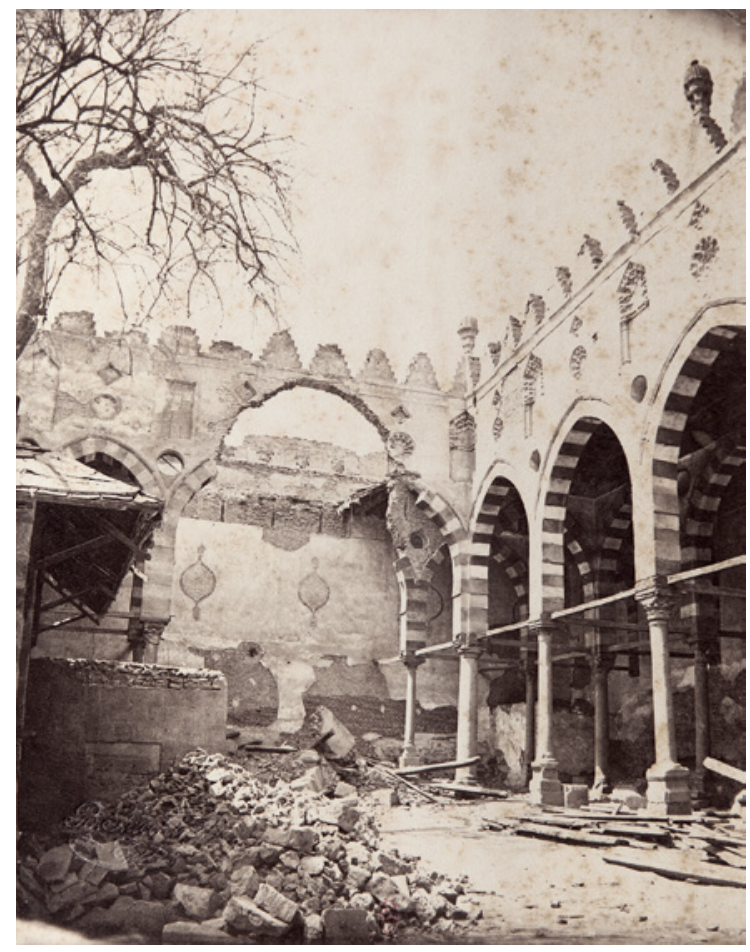

FIGURE 32 Beniamino Facchinelli, Cortile e Minareto del Mirdan (Cairo) [Courtyard of the al-Maridani Mosque after damage caused by the 1856 earthquake]. Mounted albumen print. $15 \times 19 \mathrm{~cm}$. Raccolta artistica di fotografie sull'architettura araba, ornati ecc. dal XII ${ }^{\circ}$ alXIII ${ }^{\circ}$ secolo fotografia italiana del Cav. B. Facchinelli, Cairo (Egitto) MDXxxLXXXVII [sic: XXX for CCC, i.e. 1887], f. 114 PARIS, BIBLIOTHÈQUE DE L'INHA, FOL PHOT 65

However, Meymar's star object exhibited in Paris in 1867 was neither the Lajin polygons, nor the epigraphy from al-Maridani, but a full minbar (Fig. 33), albeit one that had been heavily repaired, as can be observed today when looking closely at its canopy, base and sides. When the purchase was discussed before the Select Committee, Meymar was quoted as having stated that he had bought the pulpit from "a royal mosque," "at the time of [its] pulling down," for $£ 700$, not a negligible amount for a damaged piece when compared to the gilded candlestick in Gustave de Rothschild's collection then valued at $£_{200}$. The corresponding mosque was identified by the Egyptologist

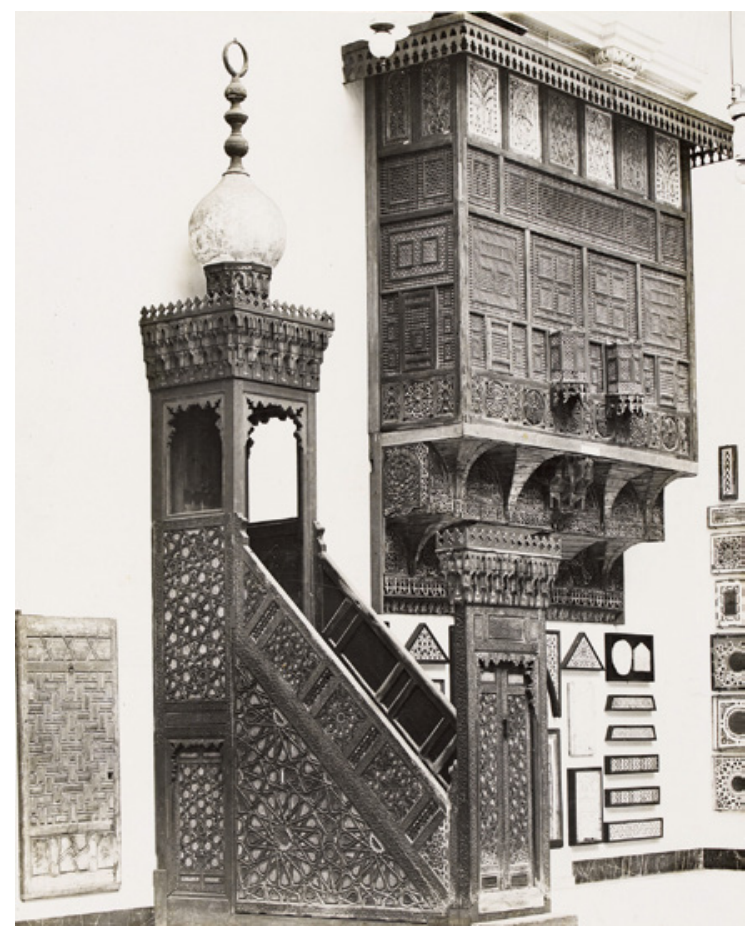

FIGURE 33 Anonymous, Pulpit, 1913. [The Qaytbay pulpit purchased from Meymar by the South Kensington Museum at the Paris Universal Exposition in 1867]. Albumen print on card. The photograph depicts object 1050-1869 LONDON, VICTORIA AND ALBERT MUSEUM, 1580-1913

Gardner Wilkinson as that of al-Mu'ayyad. ${ }^{111}$ As a matter of fact, it is known that its prayer hall had been fully restored in $1255 \mathrm{AH}$ (1839 AD) but that the mosque had experienced seismic activity in 1847. It was described in 1870 as a complete ruin, ${ }^{112}$ resulting from the enlargement of the adjoining street of Taht al-Rab. ${ }^{113}$ Other provenances for the

\footnotetext{
111 Report from the Select Committee, 18.

112 Auguste Ferdinand Mehren, "Tableau général des monuments religieux du Caire," Mélanges asiatiques tirés du bulletin de l'académie impériale des sciences de St-Pétersbourg VI (1871): 296-569 (308).

113 "Meymar collection of Arab Art: extracts from the Report of Reginald Stuart Poole," Fifteenth Report of the Science and Art Department of the Committee of Council on Education (London: H.M. Stationery office, 1868), 231-35 (232).
} 
minbar were considered as well at a later stage. As we shall see in Chapter 3 , all proved wrong and the cross-checking of sources on the pulpit's acquisition suggests that it should be more safely attributed to the Mosque of al-Sultan Shah.

In any case, Meymar's exhibits in 1867 do mark a change of scale and geography in the translocation process of Islamic artworks. In 1861, Beaucorps had managed to secure four panels from the Lajin minbar on site; six years later, there were dozens of them offered on sale in Paris, together with a full minbar.

\section{The Sale and Display of an Egyptian} Collection in 1869

Meymar's collection must have been substantial, for on 8-9 January 1869, he had ninety further lots auctioned off in Paris. ${ }^{114}$ These may be considered "left-overs," as among the pieces he had exhibited at the ${ }_{1867}$ Exposition universelle, were objects that had not been acquired by the South Kensington Museum. This was the case for armour, because the British referees considered the items "neither rare nor ancient." Brass and copper bowls and vases, "said to be of the manufacture of the Hedjaz, but which are precisely similar to objects of the same class so common in India" were similarly rejected, because the museum already had many specimens of such vessels. ${ }^{115}$ The minutes of the sale show that, as a matter of fact, most of Meymar's lots realised very modest prices (less than 100 francs per item). ${ }^{116}$ The majority falls in the category of

114 Objets arabes, koptes, koufiques et persans, bronzes, armes, tapis, appartenant en partie à M. le Dr. Meymar, et aussi à MM. Henry, des Essarts et Beaucorps, Drouot, 8-9 January 1869 [Lugt 30875].

115 Kew, The National Archives, Minute Books of the Board Meetings of the Department of Practical Art and its Successor, the Science and Art Department (18521876), ED28/22, Report From Owen Jones, August 30, 1867 , f. 211.

116 Paris, Archives de Paris, Minutes de ventes des commissaires-priseurs, Étude de maître Pillet, Ventes 1869, D. 48 E 36 o. brass and glass vessels, but there were also tiles, some jewellery, four plaques of carved ivory dating from the fifteenth century, and further folios from manuscripts. A good deal of them was acquired by dealers, possibly as stock or on order from patrons. Seventeen items (mostly salvaged carved woodwork) were moreover bought back by Husayn Fahmi, because of unsatisfactory bids. It was not a fruitful sale. Architectural salvage was yet to become a must-have.

Some of the objects withdrawn from the sale were lent to the next exhibition organised by UCAD in the fall of that same year (10 August10 November 1869). This time, the entire section of historic design was devoted to "Oriental art," covering both Islamic and Asian art. The loans to this Musée oriental amounted to more than 2,800 artworks (compared to about 500 in 1865). Husayn Fahmi loaned fifteen significant pieces, among them ceramics. Two tiles with blue background, floral ornament and a horseman with a falcon are recognisable Qajar pieces. ${ }^{117}$

He also presented carved wooden roundels and an elaborate door, both supposedly dated from the sixteenth century. ${ }^{118}$ It is very tempting to connect these two pieces with engravings published in L'Art pour tous in December 1869 and February 1870. (Fig. 34) Although the pieces do not bear the name of Meymar, they are said to have been part of the Musée oriental and are described as "sixteenth-century Arab art."119 No other pieces in the catalogue of the show fit such a description. Close examination of the published engravings reveals their almost certain provenance: the Egyptian salāmlik built at the 1867 Exposition

117 Albert Jacquemart, "Exposition de l'Union centrale des Beaux-arts appliqués à l'industrie, Musée Oriental," Gazette des beaux-arts 2 (2d period) (1st October 1869): $332-51$.

118 Exposition des Beaux-arts appliqués à l'Industrie, Guide du visiteur au Musée oriental (Paris: Union centrale, 1869), 33, 36, 37, 38 .

119 "Panneaux en bois sculpté, XVI e siècle, art arabe," L'Art pour tous, no. 241, 30 December 1869, 961; "Fragment d'une porte en bois, XVI ${ }^{\mathrm{e}}$ siècle," L'Art pour tous, no. 244, 15 February $1869,973$. 


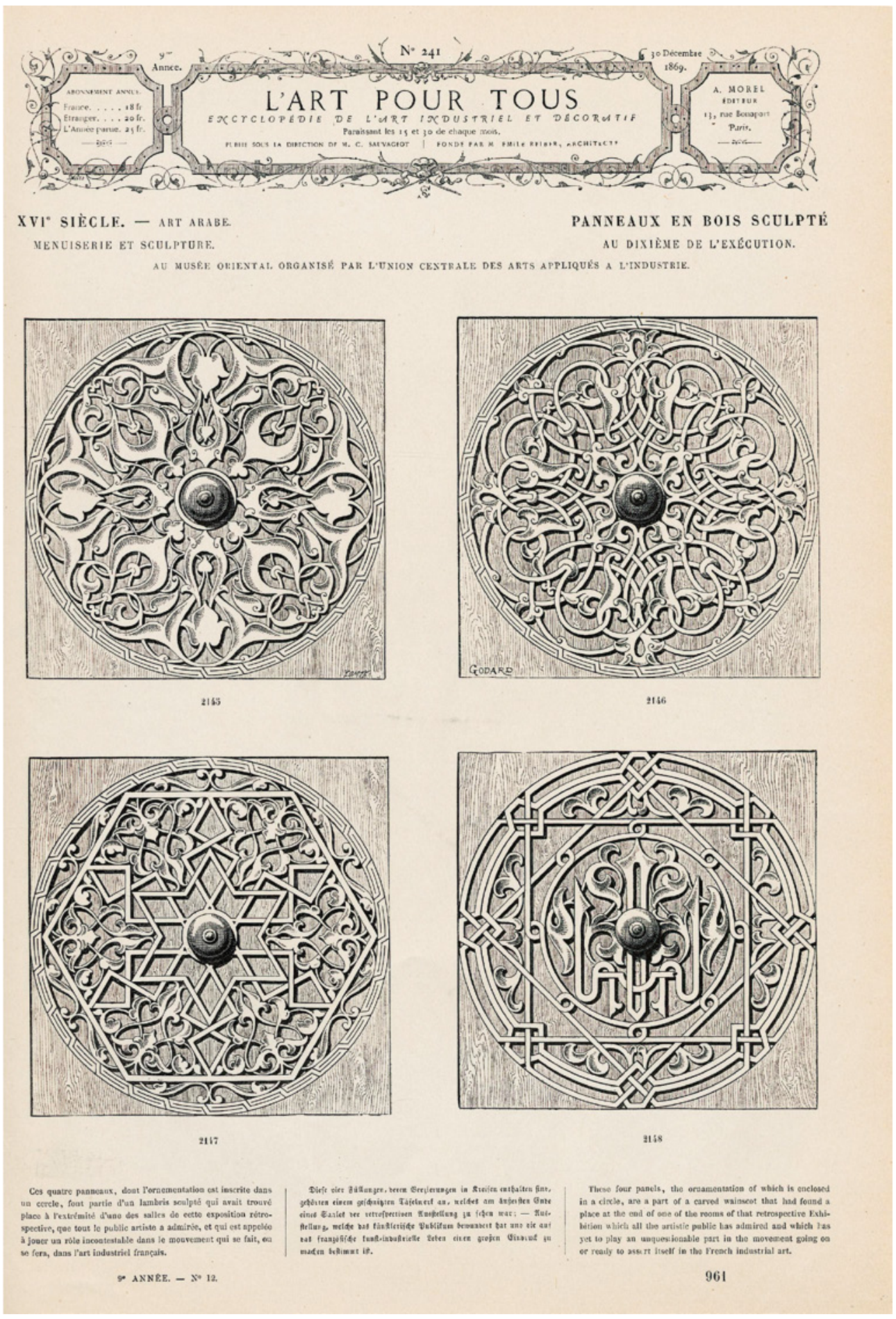

FIGURE 34 Panneaux en bois sculpté, XVI e siècle, art arabe [Carved roundels, said to be sixteenth-century, displayed at the Musée oriental in 1869]. Engraving L'ART POUR TOUS, NO. 241, 30 DECEMBER 1869, 961 
universelle. The carved roundels engraved in L'Art pour tous are of identical design to the ones repurposed in modern frames that topped the doors opening onto the central hall of the pavilion. (See Fig 24 above) The second engraving in L'Art pour tous depicts the upper part of the leaf of the door separating the central hall from the pavilion's vestibule. Their attribution to the sixteenth century is questionable. In all likelihood, the roundels (probably taken from mashrabiyas) are later (late Ottoman?), while the manufacturing of the leaf can be recognised as purely nineteenth century. Were Meymar's composite pieces mistaken, on purpose, by himself or the journal, for historic ones? Is the erroneous label a deliberate act to mislead readers? More likely, the faulty attribution is evidence rather that "stylistic dating" dominated the understanding of art during that period, or at least its dissemination to a wider public. It is very plausible that in the context of L'Art pour tous, and indeed more broadly, a piece was captioned sixteenth century because it resembled, reproduced or emulated sixteenth-century craftsmanship. In other words, the emphasis was on design rather than on historicity. Distinguishing nineteenthcentury Revival work from historic originals may be more the concern of the present-day art historian, and differences in perception have to be kept in mind when using this type of source. The boundaries between copy, interpretation and original were then thin. The focus was on style and pattern. The way Beaucorps' Iznik tile was illustrated in L'Art pour tous is another good example. (Fig. 15)

The doors published in 1869 were, without much doubt, salvaged from the Egyptian kiosk, directly or indirectly by Husayn Fahmi. It was customary to dismantle the pavilions at the end of the expositions and resell their parts; as a matter of fact, numerous structures from World's fairs were relocated across Europe in whole or part, and many other fragments reinserted into existing buildings. ${ }^{120}$ The phenomenon points to an on-

120 Gustave Delchevalerie, "L’Égypte agricole, industrielle et artistique," in Études sur l'exposition universelle going culture of recycling woodwork and building materials that was as active in France as it was in Egypt. The technique could apply just as easely to remnants from historic mosques or to material from more recent constructions. In this sense, the Islamic collections assembled during the nineteenth century were foremost the product of the recycling culture of their time.

\section{$4 \quad$ Shifting Trajectories and Contexts}

In sum, a number of findings emerge from this exploration of Islamic artefacts on public view in late Second Empire Paris. A first observation is that type, provenance, and procurement could shift rapidly. In 1865, elaborate arms and armour, precious glasswork and ceramics, and sumptuous metalwork inlaid with silver and gold dominated the exhibits. The selection reflected the standards of conspicuous consumption of luxury goods that characterised French high society at the time. ${ }^{121}$ As we have seen, most exhibitors at the 1865 loan show belonged to the higher end of French society, whether heirs of old money or recipients of recent wealth. Two years later, in 1867, a new type of collectible made its entry: salvaged woodwork. It fitted perfectly the theme of the Universal Exposition (the history of labour) and attracted the attention of the South Kensington Museum because of its potential value for modern design. In contrast it fared poorly at public auction.

Early arrivals of Islamic artefacts were mainly due to Western travellers, and came principally from Damascus, Cairo, Istanbul, Iran, and occasionally Central Asia or the Hijaz. They were mostly obtained at bazaars, although other types of dealing (e.g. an exchange of goods or purchase

Paris 1878, Annales et archives de l'industrie au XIX siècle (Paris: Librairie scientifique, industrielle et agricole E. Lacroix, 1878), 452, 547; Sylvain Ageorges, Sur les traces des expositions universelles, Paris, 1855-1937 (Paris: Parigramme, 20o6).

121 Spectaculaire Second Empire, eds. Guy Cogeval et al. (Paris: Skira, 2016). 
to individuals) are recorded. Some objects were already in Europe decades earlier and had been moving from a collection to another, or one country to another. Other sets, like the ones displayed in 1867 , were mediated to Paris through Middle Eastern agency, as the case of the engineercollector-dealer Husayn Fahmi al-mi'mār recounts.

Overlaps across the collections, on the other hand, are best explained by availability. Desire for specific pieces did spur demand; but supply equally fueled purchases in an even more crucial way. One significant episode is the weaponry that reached Europe following recurrent clearance of the old Ottoman arsenal in Istanbul from the $1830 \mathrm{os}$ onwards. It would have been much more difficult to procure otherwise. Another determinant situation was the derelict conditions of many a historic monument in Cairo. It provided the market with a new genre of material, exemplified by the salvage brought to Paris in 1867. Four mosques are connected to the artworks recalled so far: the sanctuaries of Ibn Tulun, al-Mu'ayyad, al-Gawri and al-Maridani. These buildings had either undergone heavy reconstruction in the first half of the nineteenth century, or been in a state of ruin for decades; in many instances they had lost their religious function. In fact, only exceptional circumstances permitted the purchase of major pieces from such structures. The portable assets of dilapidated mosques were subjected to financial transactions, as demonstrated by the case of the Mamluk minbar displayed for sale in Paris in 1867. Qur'an leaves were reported to have left the mausoleum of al-Gawri as early as 1858 . Other sacred folios were disposed of, at an even earlier stage, from another large building, the Madrasa of al-Sultan Barquq, as suggested by Cournault's acquisitions in Paris in $185^{\circ}$ or a bequest by Antoine Clot-Bey in $1851^{122}$ The so-called treasure of the Madrasa of Qalawun provided collectors with many luxurious specimens of metalwork. The afterlife of Islamic art in Europe cannot be disconnected from the domestic history of medieval material culture in the Middle East during the long nineteenth century, although little is known so far of its vicissitudes.

\footnotetext{
122 Brussels, Bibliothèque Royale de Belgique, Ms 19991, Luxury copy of a part of the Koran, dated $789 \mathrm{AH}$ (1387 AD), bequeathed by Antoine Clot-Bey in 1851.
} 